\title{
Long-Term Vegetation Dynamics and Disturbance History of a Tsuga-Dominated Forest in New England
}

\section{Citation}

Foster, D. R., and T. M. Zebryk. 1993. Long-Term Vegetation Dynamics and Disturbance History of a Tsuga-Dominated Forest in New England. Ecology 74, no. 4: 982-998. Portico. doi: $10.2307 / 1940468$.

\section{Published Version}

doi:10.2307/1940468

\section{Permanent link}

http://nrs.harvard.edu/urn-3:HUL.InstRepos:30675097

\section{Terms of Use}

This article was downloaded from Harvard University's DASH repository, and is made available under the terms and conditions applicable to Other Posted Material, as set forth at http:// nrs.harvard.edu/urn-3:HUL.InstRepos:dash.current.terms-of-use\#LAA

\section{Share Your Story}

The Harvard community has made this article openly available.

Please share how this access benefits you. Submit a story.

\section{Accessibility}




\title{
LONG-TERM VEGETATION DYNAMICS AND DISTURBANCE HISTORY OF A TSUGA-DOMINATED FOREST IN NEW ENGLAND ${ }^{1}$
}

\author{
D. R. FOSTER AND T. M. ZEBRYK \\ Harvard Forest, Harvard University, Petersham, Massachusetts 01366 USA
}

\begin{abstract}
The post-glacial history of two adjacent sites in the Harvard Forest, a 10ha swamp (Black Gum Swamp) and a 0.006-ha hollow (Hemlock Hollow) in a Tsuga canadensis forest were investigated using pollen analysis. The sites were selected in order to contrast the regional vegetation history revealed from the swamp sediments with the local history of the Tsuga forest reconstructed from the Hollow sediments. Specific objectives were (1) to document the natural and anthropogenic disturbance history, (2) to examine the long-term vegetation dynamics of the two sites resulting from environmental change, species migration, and disturbance, especially with respect to Tsuga, and (3) to contrast the pre- and post-settlement vegetation and environments. The Swamp and Hollow cores contain continuous sediment records covering the past 12300 and $9500 \mathrm{yr}$, respectively. Regional vegetation changes are delimited in six pollen zones: I, Herb zone (12 500-11800 yr BP); II, Picea zone (11 800-9350 yr BP); III, Pinus-Quercus zone (9350-8350 yr BP); IV, Tsuga-northern hardwoods zone (8350-1750 yr BP); V, Tsuga-Castanea-hardwoods zone (1750-200 yr BP); and, VI, Post-settlement zone (200 yr BP-present). No disturbances are detected in the periods of tundra or boreal vegetation from 12500 to $8350 \mathrm{yr}$ BP. Since 8350 yr BP three distinct disturbance processes are detectable: (1) fires recorded in discrete charcoal horizons, (2) the apparent pathogenic decline of Tsuga (4700-3500 yr BP) and the blight of Castanea $(\approx 1915$ A.D.), and (3) post-settlement forest cutting, burning, land clearance, and cultivation (1750 A.D. to present).

Log-ratio diagrams facilitate the differentiation of local vegetation history in the Tsuga forest from the regional upland history. Tsuga has been the dominant taxon at the Hollow for the last $8000 \mathrm{yr}$ although its abundance has fluctuated with disturbance. Tsuga, Ulmus, Populus, Acer rubrum, A. saccharum, Betula, and Castanea apparently are more abundant locally than in the regional vegetation, which has a larger component of Pinus, Quercus, and Carya. Post-disturbance vegetation dynamics in the Tsuga forest are controlled by the type and intensity of disturbance and the pool of available species, determined by species migration and climate change. Tsuga decreases and subsequently recovers in 300-1200 yr following most disturbances. Northern hardwood taxa (Acer saccharum, Fagus, Betula spp., Ulmus, Fraxinus) generally decrease after fire and human activity and recover with Tsuga. For the period 8000-3000 yr BP Pinus, Quercus, and occasionally Populus and Nyssa increase following fire and the Tsuga decline at $4700 \mathrm{yr}$ BP. However, since its immigration at $\approx 3000$ yr BP Castanea has been the major species to increase upon disturbance of the Tsuga-northern hardwood forest. The study documents the long-term dominance of a forest stand by Tsuga canadensis and northern hardwood species despite repeated infrequent disturbances. The ability of these taxa to gradually reassume their former abundance following disturbance is presumably a consequence of their shade tolerance and longevity and the low frequency of disturbance.
\end{abstract}

Key words: Castanea dentata; disturbance; fire; hemlock; long-term vegetation dynamics; natural and anthropogenic disturbances; New England; pollen analysis; pre- vs. post-settlement vegetation; regional vs. local forest history; Tsuga canadensis.

\section{INTRODUCTION}

One of the major objectives of recent paleoecological research has been to forge relevant linkages with ecological studies undertaken at the landscape, community, and population level (Allison et al. 1986, Bennett and Lamb 1988, Prentice 1988, Schoonmaker and Foster 1991). This linkage has been attempted by focusing

${ }^{1}$ Manuscript received 22 April 1991; revised 15 May 1992; accepted 5 July 1992. paleoecological investigations on processes and patterns that are important to modern studies (e.g., vegetation response to disturbance, time lags of response to environmental change (Davis and Botkin 1985, Clark 1990)), and temporal and spatial scales that are complementary to population, community, and landscape ecology (Bradshaw 1988, Turner and Peglar 1988). Such paleoecological research has increased our understanding of: (1) ecological processes that require long periods of time or show high variance, (2) organism responses 
over a range of spatial scales and to a wide range of environmental variation, and (3) contrasts in the characteristics and dynamics of biological systems in periods before extensive human activity with periods of anthropogenic activity (Foster et al. 1990).

In the current study the vegetation dynamics and disturbance history of a forest dominated by Tsuga canadensis was investigated from post-glacial time through the period of European settlement. We used sedimentary basins that collect different amounts of regional vs. local pollen from the upland forest in order to resolve contrasting scales of vegetation in the landscape (cf. Faegri 1954). The sites investigated include (1) a small hollow in a Tsuga forest that predominantly receives pollen from the surrounding trees, and (2) an adjacent swamp that receives pollen from upland taxa over a broader region (e.g., Jacobson and Bradshaw 1981, Patterson et al. 1987, Mitchell 1988, Foster et al. 1992). Comparison of these pollen records should provide a history of regional vegetation change in response to environmental change and species migrations as well as a local record of stand-level dynamics resulting from these factors and from local events.

The Tsuga forest and swamp are surrounded to the north and southeast by hills and by low, swampy ground to the east (Figs. 1 and 2). This physiographic setting provides an opportunity to focus specifically on (1) the Holocene history of Tsuga, a species frequently found on mesic, protected sites (Rogers 1978), (2) the dis-

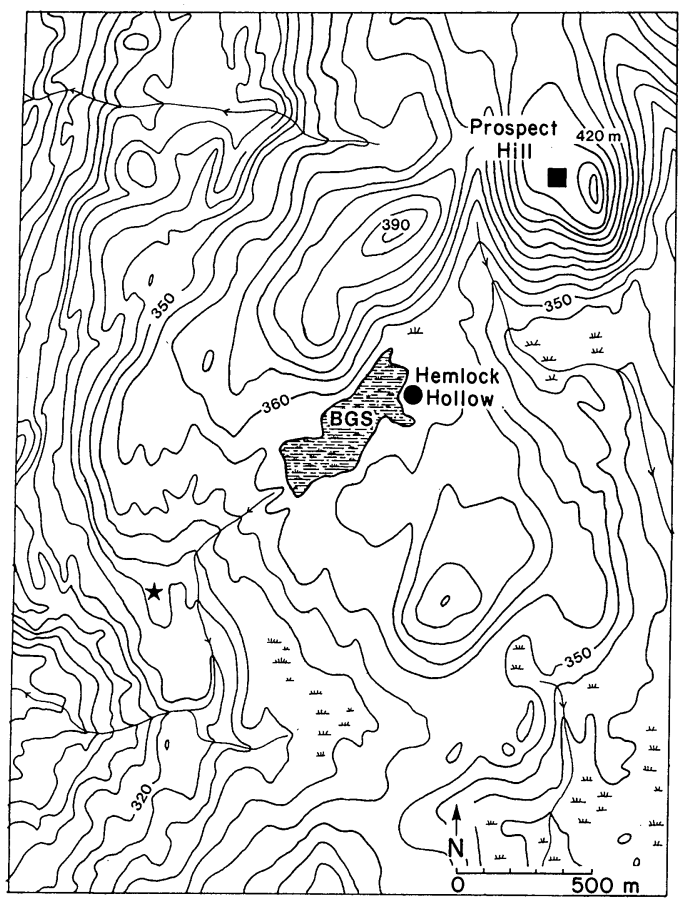

FIG. 1. Topographic map of the central Massachusetts, USA, study region (5-m contours) showing wetlands, streams, and the location of the Black Gum Swamp (BGS), Hemlock Hollow, and Harvard Forest headquarters (star).

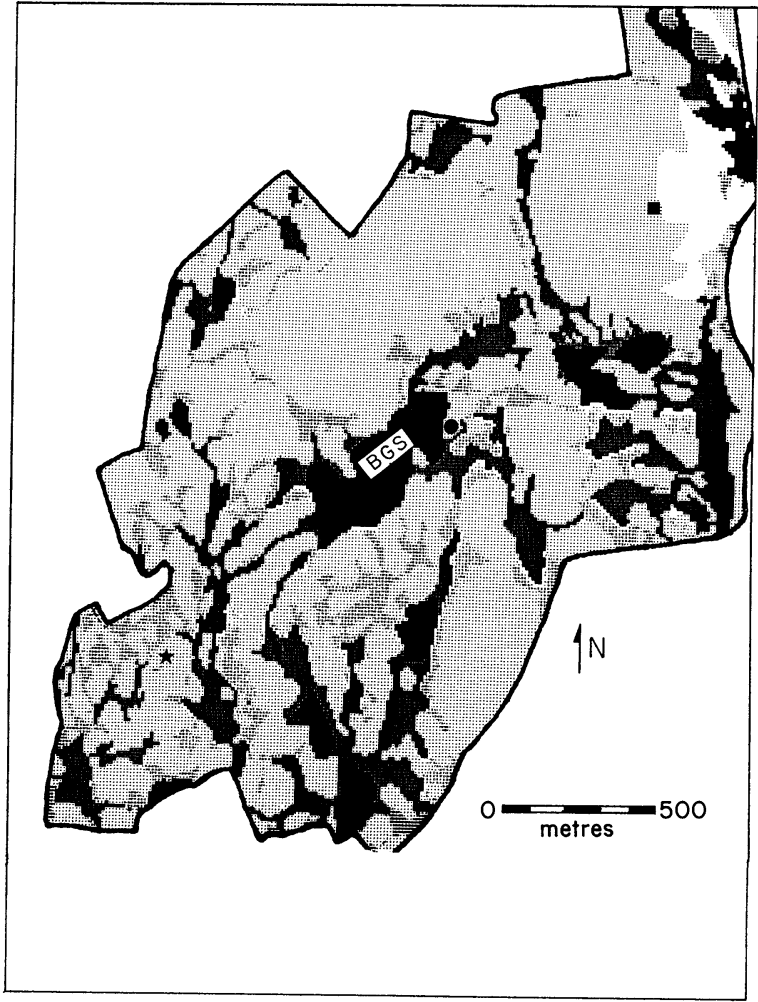

Fig. 2. Soil drainage characteristics of the Prospect Hill tract of the Harvard Forest. Locational symbols follow Fig 1. Five drainage classes are represented, ranging from very well (white), well, imperfectly, poorly, to very poorly drained (black), following Spurr (1956).

turbance history of a physiographically sheltered site, and (3) the dynamics of species that are poorly represented in palynological studies due to their low regional abundance, preference for geographically restricted sites, and/or low pollen representation.

The history and role of Tsuga in the pre- and postsettlement forests of the northeastern United States is particularly interesting (Davis 1969, 1981). Tsuga is a long-lived, extremely shade-tolerant tree that may establish and persist under a closed canopy or in canopy gaps (Merrill and Hawley 1924). Despite slow rates of growth it may achieve canopy dominance through release following opening in the overstory (Marshall 1927, Oliver and Stephens 1977, Kelty 1986). Due to its autecology and presence in many old-growth forests in the northeastern United States, Tsuga is often cited as a climax species, along with Acer saccharum, Fagus grandifolia, Betula lutea, and Quercus rubra (Nichols 1913, Lutz 1930a, Cline and Spurr 1942, Hough and Forbes 1943, Bormann and Buell 1964).

Tsuga, however, is susceptible to disturbance and environmental stress (e.g., fire, wind, pathogens, and drought), and thus its landscape distribution is thought to be partially explained by physiographic control of these processes (Cline and Spurr 1942, Niering and 
Goodwin 1974, Rogers 1978, Foster 1988) and by anthropogenic activity following settlement (Nichols 1913, Smith 1950). This study seeks to investigate changes in the long-term abundance of Tsuga and to clarify Tsuga's relationship to disturbance.

Our second focus was to compile a long-term record of disturbance. Central Massachusetts apparently occupies an intermediate location on a regional disturbance gradient from relatively frequent occurrence of fire and hurricane winds in southern and coastal areas to very low incidence of disturbance in northern inland sites (Backman 1984, Foster 1988, Patterson and Sassaman 1987). However, no long-term disturbance histories of central New England exist. The available reconstructions of disturbance focus on exposed, upland areas that are relatively susceptible to fire and wind damage (Cline and Spurr 1942, Henry and Swan 1974, Foster 1988), or on sites with a long history of human activities (Stephens 1955, Oliver and Stephens 1977). The two relatively sheltered sites investigated in the current study are presumably of generally low susceptibility to broad-scale disturbance. Thus, this study seeks to provide a long-term record from a site type and region poorly represented in prior disturbance studies.

Finally, this study seeks to explore the history of taxa that are poorly represented in the pollen record. This includes species of low regional abundance (e.g., Picea rubens, Nyssa sylvatica, Ulmus spp., Acer saccharum) and species that are generally underrepresented due to either low pollen production or dispersal (e.g., Castanea dentata, Acer rubrum). As a result of the strong local pollen signal contained in sediments of forest hollows this study should be able to further elucidate the history of these taxa.

\section{Study Area}

The Harvard Forest is located in the Central Uplands physiographic region of Massachusetts (Motts and O'Brien 1981), an area characterized by rolling northsouth-trending ridges and acidic Paleozoic bedrock overlain by thin glacial till. The vegetation is typical of the Transition Hardwood-Hemlock-White Pine forest region (Westveld 1956, Spurr 1956).

The Black Gum Swamp (BGS) occupies an irregularly shaped basin 10 ha in area and $5 \mathrm{~m}$ in maximum depth that drains to the southwest through an intermittent stream (Fig. 3). Prominent hills surround BGS to the north and northeast (Fig. 1). Swamp vegetation is dominated by Picea rubens, Nyssa sylvatica, and Acer rubrum in the overstory, Ilex, Nemopanthus, Vaccinium, and Viburnum spp. in the understory, and a ground layer of Sphagnum, Osmunda, and herbs. Within the watershed the second-growth forest on the dry upland soils to the northwest contains Quercus spp., Fagus grandifolia, Acer rubrum, Betula populifolia, and Populus spp. To the northeast and east of BGS a 5-ha stand of Tsuga canadensis with occasional Pinus strobus, Pic- ea rubens, Quercus rubra, Betula lutea, Fagus, and Acer rubrum occurs on moist, mor-humus soils (Fig. 2). The Tsuga stand and the swamp forest were wooded continuously throughout the settlement period, although both were heavily cut (Raup and Carlson 1941, Foster 1992).

The Hemlock Hollow $(\mathrm{HH})$ is located in the middle of the Tsuga stand $\approx 50 \mathrm{~m}$ east of Black Gum Swamp (Figs. 1 and 3). HH occupies a depression $4 \times 15 \mathrm{~m}$ in size with a maximum sediment depth of $0.8 \mathrm{~m}$ (Fig. 4). It is seasonally flooded but has no inlets or outlets and is covered by a thin mat of bryophytes and leaf litter. $\mathrm{HH}$ supports a vegetation of Ilex verticillata and Vaccinium corymbosum in the shallow center, and sedges, grasses, Osmunda cinnamomea, and Sphagnum around the margins. The irregular canopy gap in the Tsuga forest above $\mathrm{HH}$ is $\approx 3 \times 10 \mathrm{~m}$.

\section{METHODS \\ Field studies}

Morphometric maps of the sites were constructed by probing with thin steel rods across a $25-\mathrm{m}$ grid at Black Gum Swamp (BGS) and 1-m grid at Hemlock Hollow (HH). A total of $500 \mathrm{~cm}$ of sediment core length was obtained with a $5 \mathrm{~cm}$ diameter Russian corer from the deepest part of the BGS basin. A $5 \mathrm{~cm}$ diameter piston corer was used at $\mathrm{HH}$ to obtain $72 \mathrm{~cm}$ of sediment core. Cores were extruded and described in the field, wrapped in plastic and aluminum foil, and transported to the laboratory.

\section{Laboratory studies}

Cores were sub-sampled volumetrically for pollen and charcoal analysis at measured stratigraphic intervals $(10 \mathrm{~cm}$ at $B G S$ and $1 \mathrm{~cm}$ at $\mathrm{HH})$. Samples were spiked with eucalyptus-glycerine solution and processed using the method of Faegri and Iverson (1975) as modified by E. J. Cushing (personal communication). A minimum of 300 arboreal pollen grains were identified at each level. Charcoal ( $>15 \mu \mathrm{m}$ longest dimension) was tallied for the entire core at BGS and for the last $3000 \mathrm{yr}$ at $\mathrm{HH}$ using the point-intercept method (Clark 1982), with a minimum number of 10000 points applied for each sample. Discrete horizons and coarse fragments of charcoal were identified at $10 \times$ magnification during the description of the gross stratigraphy. Pollen percentage diagrams for upland taxa are based on a sum excluding spores, aquatic taxa, and wetland taxa. Percentage diagrams for taxa excluded from the upland sum are based on the total pollen sum.

Organic carbon content was determined by loss-onignition $\left(\right.$ at $\left.550^{\circ} \mathrm{C}\right)$ at $10-\mathrm{cm}$ intervals at $\mathrm{BGS}$ and $1-\mathrm{cm}$ intervals at HH (Dean 1974). Seven levels at BGS were sampled for ${ }^{14} \mathrm{C}$ dating (Table 1). The chronostratigraphy at $\mathrm{HH}$ is based on an accelerator ${ }^{14} \mathrm{C}$ date of the basal sediments and pollen-stratigraphic correlation with the dated BGS core. Regional upland pollen events 


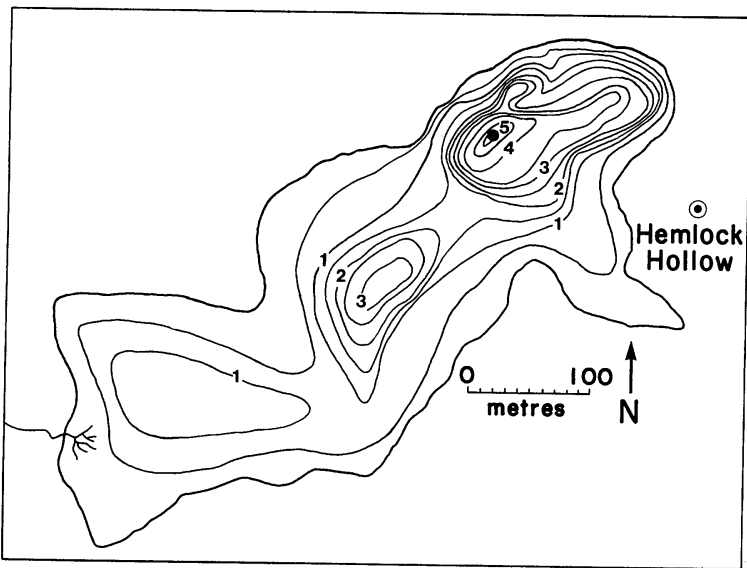

FIG. 3. Morphometric map (elevation contours in metres) of the Black Gum Swamp showing the shallow and deep basins, the coring location (๑), and the location of the Hemlock Hollow $(\odot)$.

that have been consistently identified by other researchers (Davis 1958, Whitehead 1979, Gaudreau and Webb 1985) were selected for correlation, including: end of the late-glacial spruce zone; Fagus increase; midHolocene Tsuga decline; Carya increase; late-Holocene Picea increase; settlement horizon; and Ambrosia peak.

\section{Multivariate analysis}

Pollen data from each site were ordinated separately using detrended correspondence analysis (DECORANA; Hill and Gauch 1980) to analyze relationships among species and samples. Samples consisted of the pollen assemblages at individual stratigraphic levels, whereas species included all upland taxa that either exceeded an abundance of $1 \%$ in any level or were consistently represented in many levels.

\section{Log-ratio diagrams}

Once time-stratigraphic correlations between the two diagrams were established, direct comparison of taxonby-taxon differences in the diagrams was made utilizing log-ratio diagrams of the percentage data following the procedure of Jacobson (1979). The two cores were first subdivided into 19 units, each comprising 1-5 stratigraphic levels that could be matched chronologically. The pollen data within each unit were averaged and

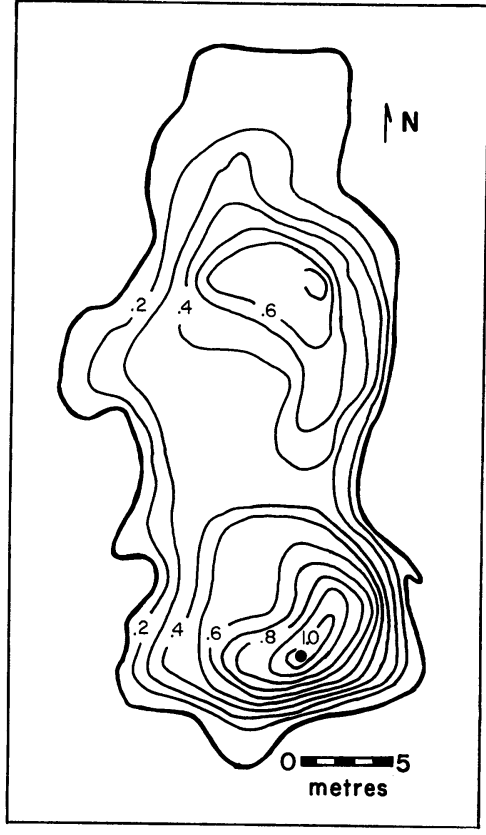

Fig. 4. Morphometric map of the Hemlock Hollow (elevation contours in metres below high water in spring 1989) showing the core location ( $\bullet$ in the deepest part of the basin. Depths include $20 \mathrm{~cm}$ of leaf litter and standing water.

the unit-by-unit comparison for each taxon was made by calculating the logarithm of the ratio of the mean percentages in the two cores. Successive values of the $\log$ ratio were then plotted around a zero axis.

\section{RESUlTS}

\section{Sediment stratigraphy}

Sediment cores from Black Gum Swamp (BGS) exhibit a well-defined stratigraphy with sharp transitions between glacial silt, gyttja, sedge-shrub peat, and woody peat. Organic content increases steadily through the transition from minerogenic glacial sediments to gyttja (Fig. 5). A sharp decrease in the organic content of the gyttja occurs at $\approx 10300-9800$ yr BP; values subsequently rise and then increase through the sedge-shrub and woody peat. Sedimentation rate changes with sediment type (Fig. 6). Gyttja was deposited at the rate of $0.046 \mathrm{~cm} / \mathrm{yr}$ from 11690 to $9750 \mathrm{yr}$ BP but then increased to $0.204 \mathrm{~cm} / \mathrm{yr}$ (9750-8560 yr BP). Sedge-shrub

TABLE 1. Radiocarbon dates from Black Gum Swamp sediment core.

\begin{tabular}{clcc}
\hline \hline Depth of sample $(\mathrm{cm})$ & Sediment type & Sample code & Radiocarbon age (yr BP) \\
\hline $450-465$ & Gyttja & BA-31366 & $11690 \pm 140$ \\
$370.5-377.5$ & Gyttja & BA-29919 & $9750 \pm 450$ \\
$280-290$ & Gyttja & BA-31365 & $8910 \pm 120$ \\
$240-250$ & Shrub-sedge peat & BA-31364 & $8680 \pm 120$ \\
$202-208$ & Shrub-sedge peat & BA-29917 & $8560 \pm 140$ \\
$160-170$ & Bog-forest peat & BA-31363 & $7580 \pm 90$ \\
$70.5-75.5$ & Bog-forest peat & BA-29916 & $3340 \pm 110$ \\
\hline
\end{tabular}




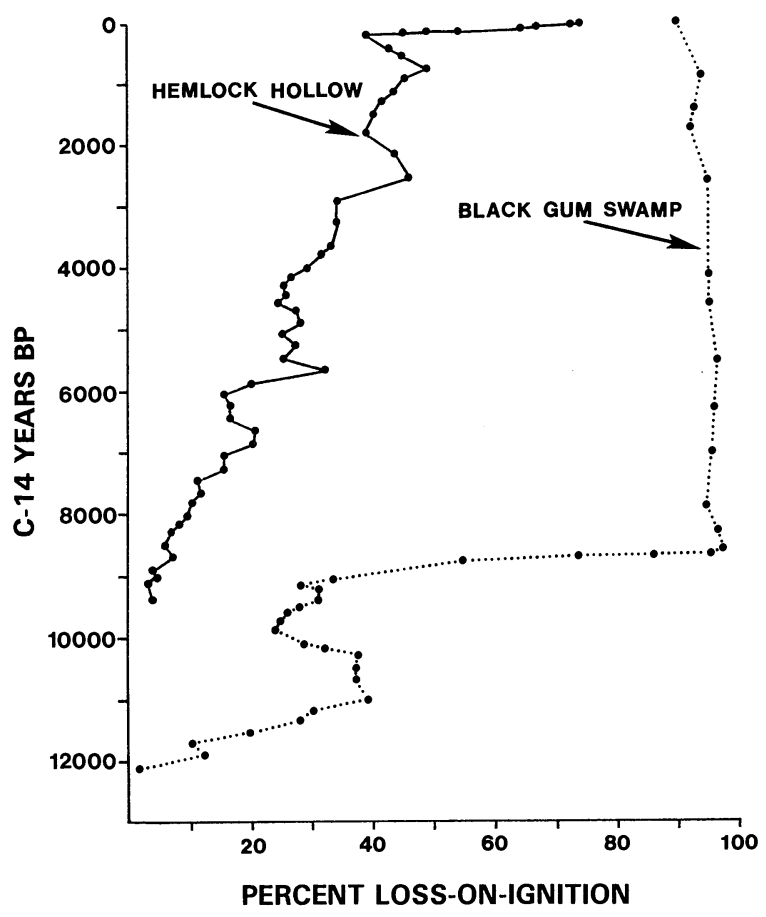

FIG. 5. Temporal profile of loss-on-ignition (organic content) for the cores at the Black Gum Swamp and Hemlock Hollow.

peat and woody peat accumulated at rates from 0.040 $\mathrm{cm} / \mathrm{yr}$ to $0.022 \mathrm{~cm} / \mathrm{yr}$ until $\approx 200 \mathrm{yr}$ BP $(1750$ A.D.) when it increased to $0.100 \mathrm{~cm} / \mathrm{yr}$. At Hemlock Hollow $(\mathrm{HH})$ the sediment is characterized by gradational contacts and subtle changes in color and texture. Organic content increases progressively over the entire length of the core, from $4 \%$ in the basal minerogenic sediment to $75 \%$ at the top (Fig. 5). Sedimentation rate is nearly constant (Fig. 6).

\section{Pollen stratigraphy}

The pollen diagrams were classified into informal pollen zones I-VI (Figs. 7 and 8) on the basis of visual inspection and the DECORANA output (Figs. 9 and 10). These local pollen zones are similar to regional pollen zones recognized in earlier studies (Deevey 1943, 1951, Davis 1958, 1969, Gaudreau and Webb 1985) and include: I, Herb zone (12 500-11 800 yr BP); II, Picea (11 800-9350 yr BP; III, Pinus-Quercus zone (9350-8350 yr BP); IV, Tsuga-northern hardwoods zone (8350-1750 yr BP); V, Tsuga-Castanea-hardwoods zone (1750-200 yr BP); and VI, Post-settlement zone (200 yr BP-present).

\section{Fire history}

With the exception of two counts at BGS $(\approx 4400$ and $11200 \mathrm{yr}$ BP), microscopic charcoal values are low (i.e., charcoal-to-pollen ratios of 5 to 110) in comparison with other studies (e.g., average C:P ratios of 250-715 for eastern Massachusetts; Backman 1984,

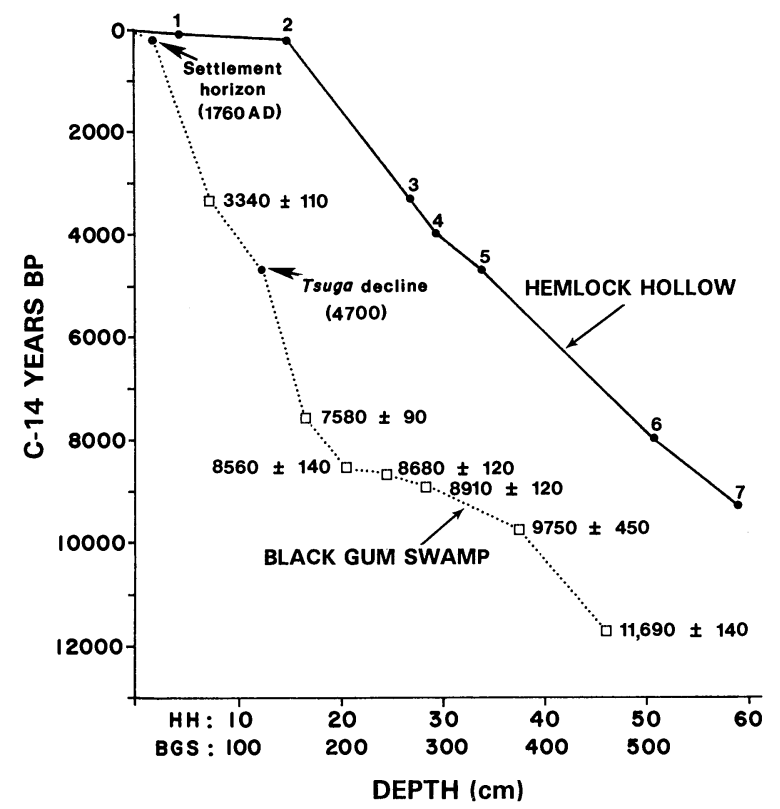

FIG. 6. Sedimentation curves for the cores from the two basins. Sediment age at Black Gum Swamp is determined by radiocarbon dating and through correlation with the regional decline of Tsuga (4700 yr BP) and the first appearance of pollen of settlement indicators (1760 A.D.). (With the exception of historical-time dates [A.D.], all ages are in years before the present.) Ages at the Hemlock Hollow are determined through correlation with the core from Black Gum Swamp based on the following biostratigraphic changes (numbered along curve): (1) Ambrosia rise (1810 A.D.), (2) settlement indicators (1760 A.D.), (3) regional Picea increase (3340 yr BP), (4) Carya increase ( $>2 \% ; 4000$ yr BP), (5) Tsuga decline (4700 yr BP), (6) regional Betula increase (8000 yr BP), (7) Picea maximum (9300 yr BP).

Patterson and Backman 1988). We identified fires only where discrete macroscopic charcoal layers occurred (cf. Tolonen 1985, Patterson et al. 1987). In addition to being a conservative, yet positive, identification of

TABlE 2. Depth and age of charcoal horizons at the two Massachusetts sites. Horizons that are judged to be contemporaneous are listed on the same line. A total of eleven temporally distinct horizons are identified.

\begin{tabular}{|c|c|c|c|}
\hline \multicolumn{2}{|c|}{ Hemlock Hollow } & \multicolumn{2}{|c|}{ Black Gum Swamp } \\
\hline $\begin{array}{l}\text { Depth } \\
\text { (cm) }\end{array}$ & $\begin{array}{c}\text { Date } \\
\text { (yr BP) }\end{array}$ & $\begin{array}{c}\text { Date } \\
\text { (yr BP) }\end{array}$ & $\begin{array}{l}\text { Depth } \\
\text { (cm) }\end{array}$ \\
\hline $\begin{array}{l}49 \\
43.5 \\
41.5\end{array}$ & $\begin{array}{l}7650 \\
6650 \\
6150\end{array}$ & $\begin{array}{c}7950 \\
7700 \\
6900 \\
\ldots\end{array}$ & $\begin{array}{c}178 \\
172 \\
156 \\
\cdots\end{array}$ \\
\hline 34 & 4700 & $\begin{array}{l}5750 \\
4400 \\
3900 \\
3600 \\
3200\end{array}$ & $\begin{array}{c}138 \\
110 \\
93-95 \\
80-86 \\
66-73\end{array}$ \\
\hline $\begin{array}{c}19.5 \\
10-13\end{array}$ & $\begin{array}{c}1900 \\
160-180 \\
(1770-1790 \text { A.D. })\end{array}$ & $\begin{array}{l}\ldots \\
\ldots\end{array}$ & $\begin{array}{l}\ldots \\
\ldots\end{array}$ \\
\hline & 6 Horizons & $8 \mathrm{H}$ & zons \\
\hline
\end{tabular}




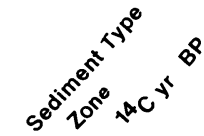

8
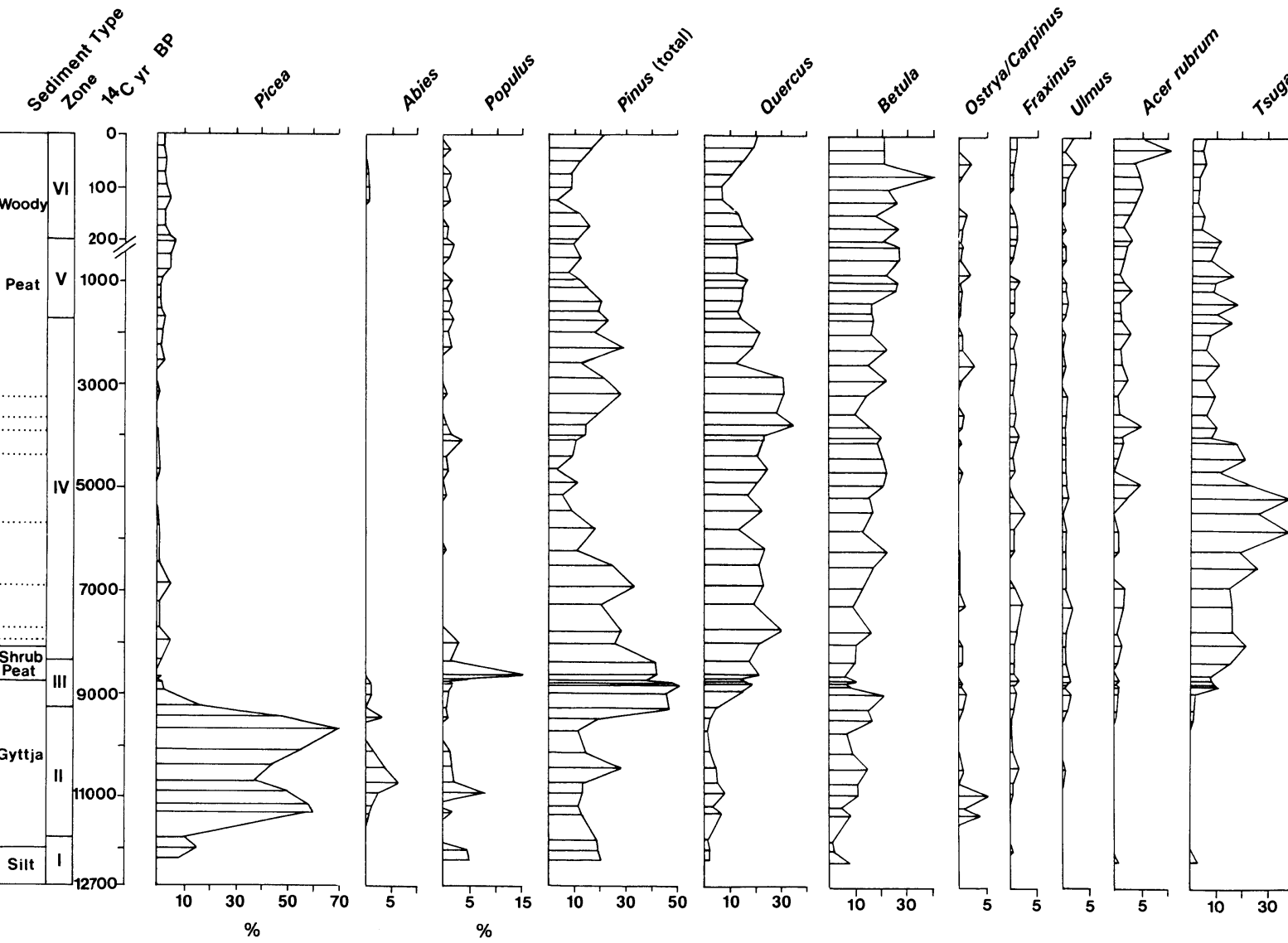

Charcoal

Fig. 7. Pollen diagram from the Black Gum Swamp showing arboreal taxa and non-arboreal taxa separately. Note that the temporal scale on the vertical axis changes at $200 \mathrm{yr}$ BP. 


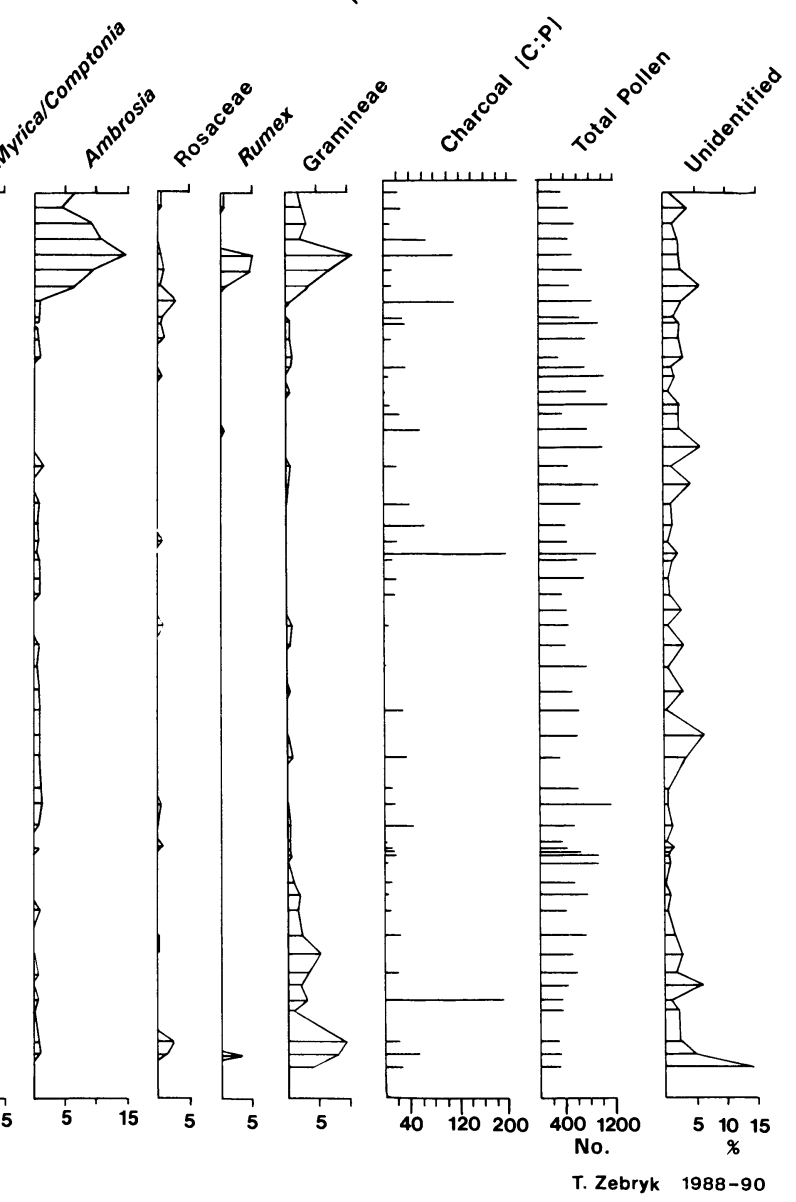




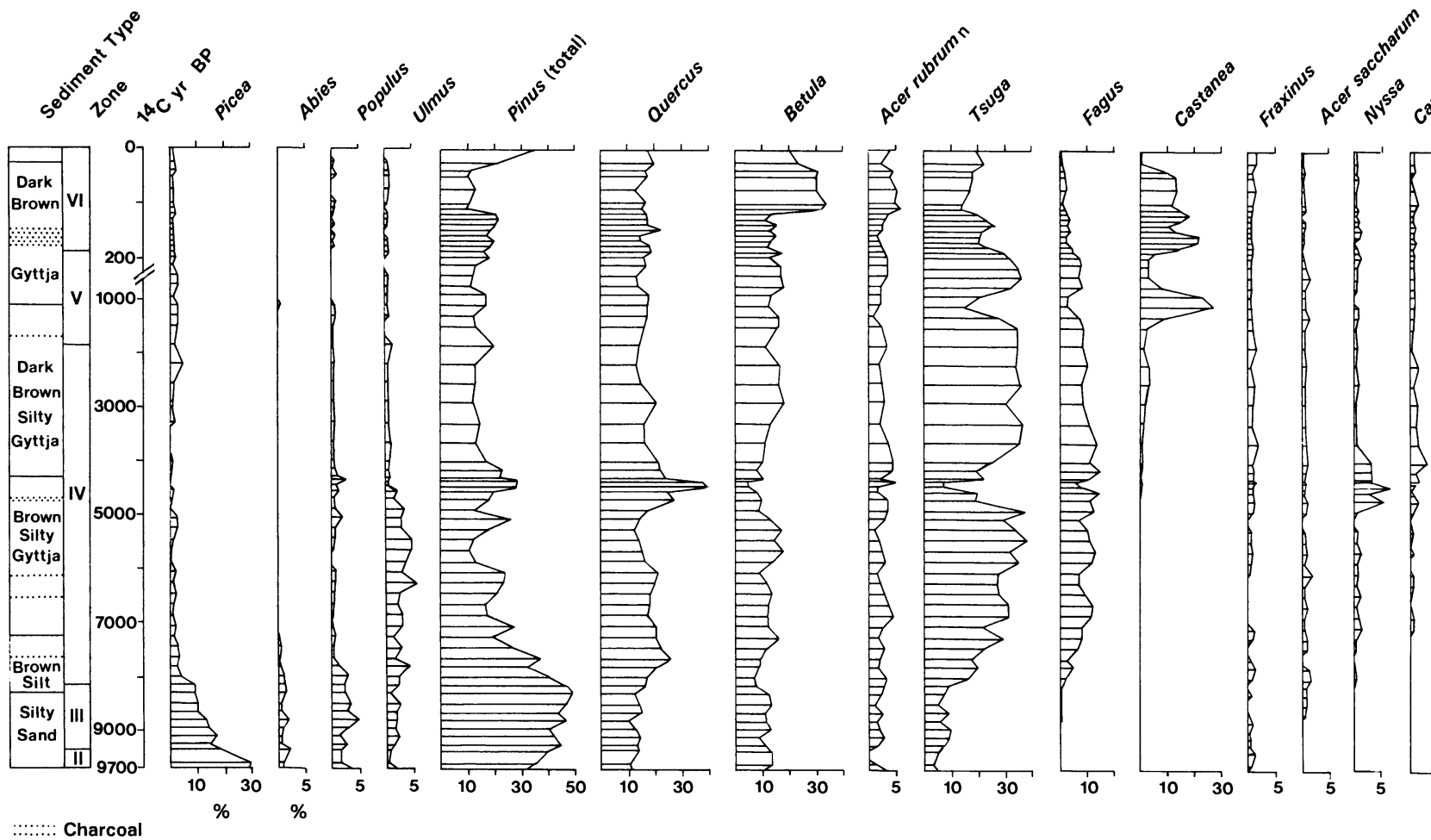

Fig. 8. Pollen diagram from the Hemlock Hollow showing arboreal taxa and non-arboreal taxa separately. Note that the temporal scale on the vertical axis changes at $200 \mathrm{yr}$ BP and that microscopic charcoal was only tallied for the last $3000 \mathrm{yr}$ at this site. 


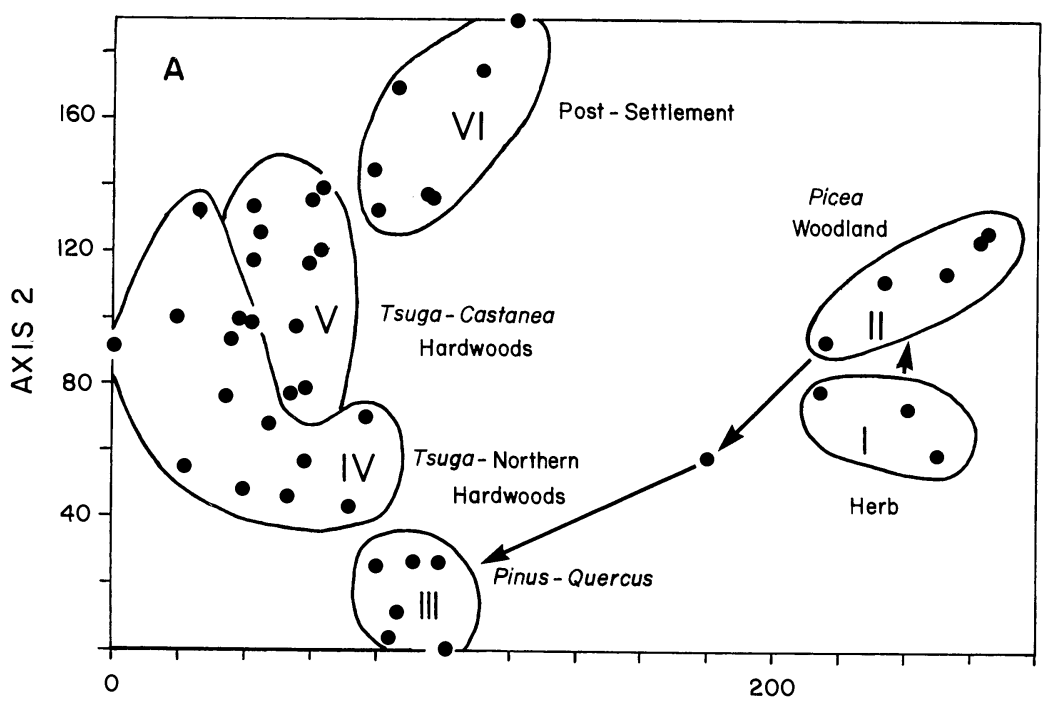

AXIS I

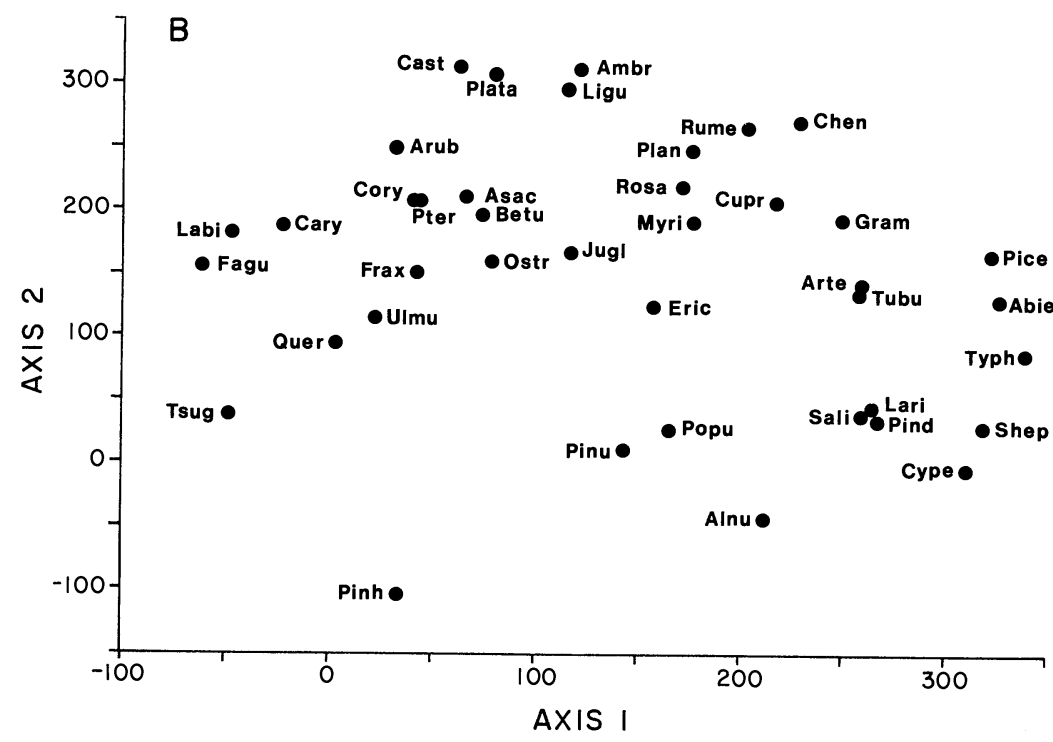

FIG. 9. Results from the DECORANA analysis of the Black Gum Swamp pollen data showing (A) sample positions and (B) species positions along the first two DECORANA axes. Sample pollen assemblages are grouped into informal pollen assemblage zones (I-VI). Taxon abbreviations use the first four letters of the genus or family with the following exceptions: Asac $=$ Acer saccharum, Arub $=$ Acer rubrum, Pinh $=$ haploxylon pine, and Pind $=$ diploxylon pine.

fire at a site, the recognition of charcoal layers does not involve many of the confounding aspects of microscopic charcoal analysis-e.g., resuspension, erosion, and variable-distance transport (Clark 1990).

At BGS a total of eight charcoal horizons occur in the woody peat (Table 2) whereas six layers were identified at $\mathrm{HH}$. Three layers were judged to be contemporaneous at the sites: 7650-7700 yr BP, 6650-6900 yr BP, and 4400-4700 yr BP. Thus a total of 11 fire episodes were recorded at the two sites during the last $8000 \mathrm{yr}$. The most recent fire occurred during the postsettlement period at the $\mathrm{HH}$ and is comprised of a band $3 \mathrm{~cm}$ wide, which may represent more than one fire.

\section{Multivariate analysis}

Results from species and sample ordinations are similar at the two sites and display the broad characteristics of the pollen diagrams while elucidating the vegetation dynamics (Figs. 9 and 10). The species ordinations separate the late-glacial and Holocene taxa along Axis 1 and early Holocene and late Holocene/post-settlement taxa along Axis 2. Taxa dominant in Zones I and II (e.g., Abies, Artemisia, Cyperaceae, Larix, Picea, Salix) have high loadings along Axis 1 (Figs. 9B and 10B). Located between these taxa and the temperate forest groupings are taxa char- 

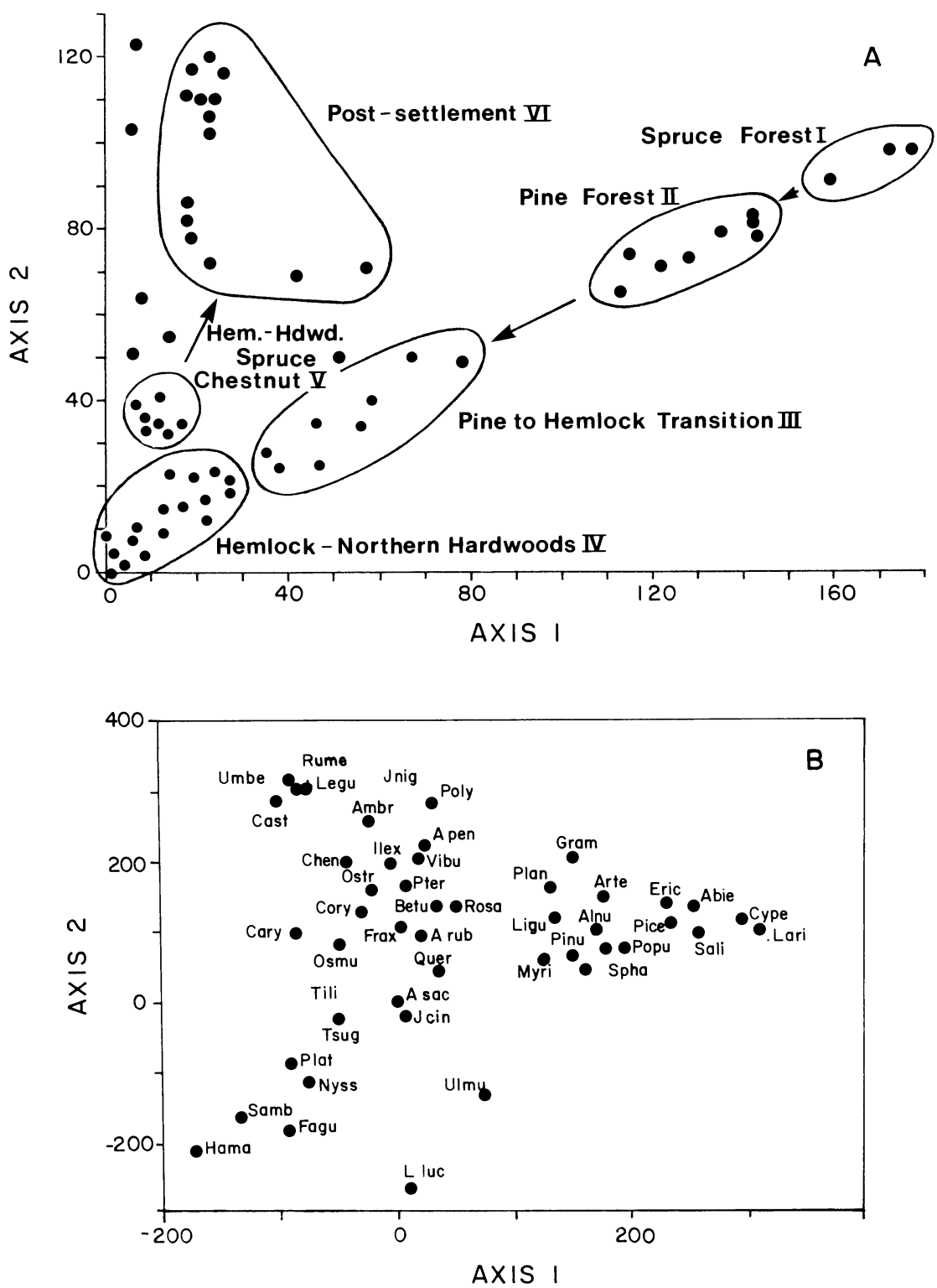

FIG. 10. Results from the DECORANA analysis of the Hemlock Hollow pollen data showing (A) sample positions and (B) species positions along the first two DECORANA axes. See Fig. 9 caption for further explanation. Additional taxon abbreviations include Jnig $=$ Juglans nigra, Jcin $=J$. cinera, Apen $=$ Acer pensylvanica, Arub $=A$. rubrum, and Lluc $=$ Lycopodium lucidulum.

acteristic of Zone III-the Pinus-Quercus zone (e.g., Alnus, Ericaceae, Pinus, Populus, Sphagnum). Along Axis 2 forest taxa that are important during the early Holocene (e.g., Ulmus, Fagus) or throughout the Holocene (e.g., Acer saccharum, Nyssa, Quercus, Tilia) have low loadings. Higher along the axis are species that either migrate into the area (Carya, Juglans nigra) or increase in importance in the late Holocene (Acer rubrum, Betula, Castanea, Ostrya, Pteridium) and during post-settlement times (Ambrosia, Cornus canadensis, Rumex, Umbelliferae; cf. Gaudreau and Webb 1985).
Sample positions along the first two axes fall into relatively discrete groups that comprise the local pollen assemblage zones (Figs. 9A and 10A). Samples representative of Zones I (BGS only), II, and III are distinctly separate and illustrate the change from predominantly late-glacial assemblages to temperate assemblages. Nearly half of the samples at both sites fall into zones IV and V (8350-200 yr BP), which are tightly clustered in the graphs, especially at BGS. The major distinction between the two groups of samples is the slightly higher position of Zone $\mathrm{V}$ samples along Axis 2, which reflects the increase of Picea and Cas- 

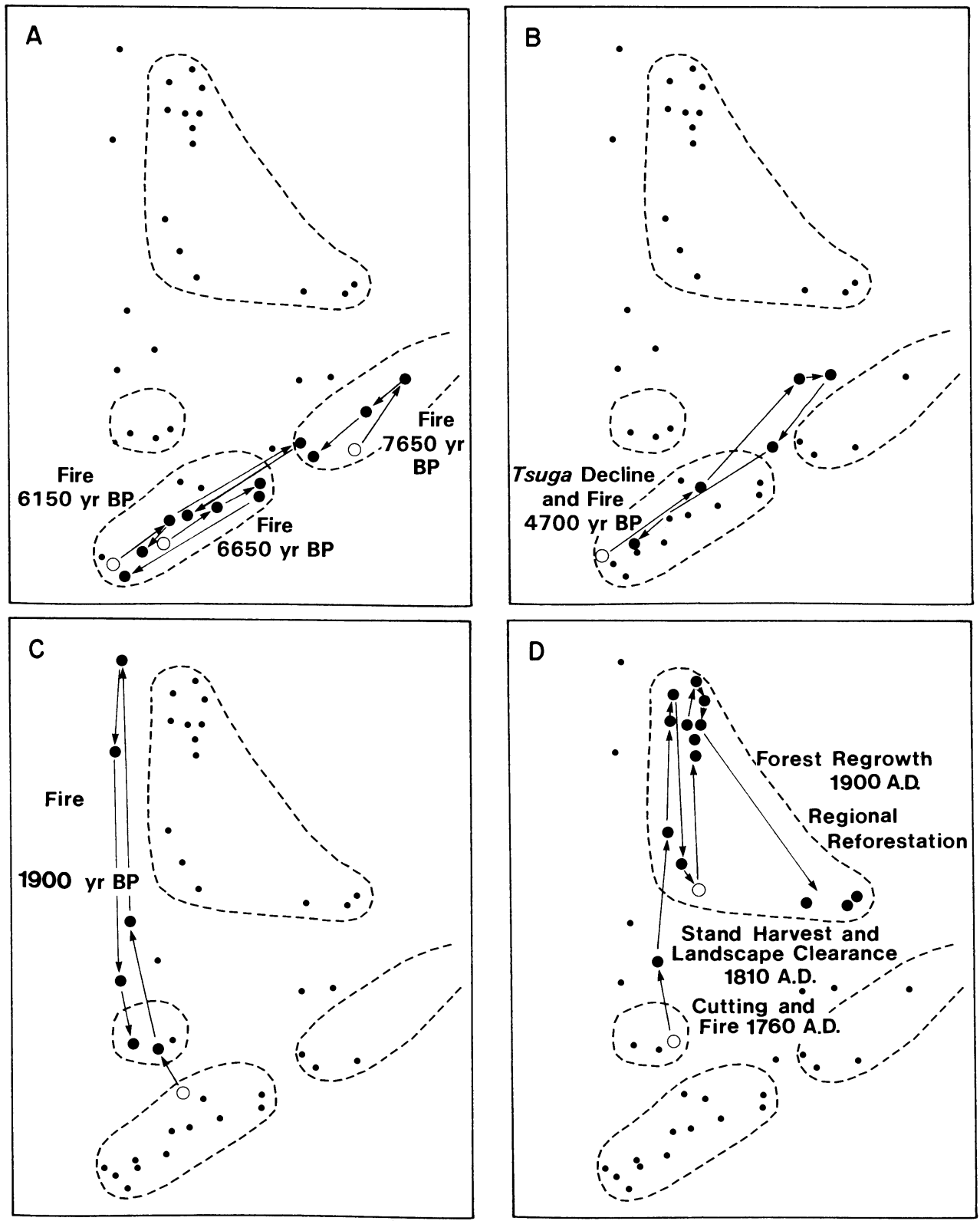

FIG. 11. Detail of the DECORANA output from the Hemlock Hollow showing the position of the mid-Holocene to modern samples on the first two DECORANA axes. - - - refer to the pollen zone groupings indicated on the left side of Fig. 10A. Arrows connect temporally contiguous samples following a disturbance that is listed adjacent to the samples. Sample movements reflect changes in pollen assemblages following disturbances. $O$ indicate sample positions before the disturbance whereas connected by lines and arrows indicate post-disturbance positions.

tanea and the decrease of Fagus. Zone VI is represented by a large number of samples that are relatively widely dispersed in DECORANA space.

Within the Holocene portion of the Hemlock Hollow graph (Fig. 11) close examination of the relative positions of the samples in conjunction with the pollen diagram and charcoal stratigraphy reveals dynamics of the local vegetation in response to disturbance. The ordination integrates all of the taxon responses and thereby illustrates changes that are subtle and involve different species on the pollen diagram. Between 7800 and $4150 \mathrm{yr}$ BP (Fig. 11 A and B) there are four discrete disturbances: three fires $(7650,6650$, and $6150 \mathrm{yr} \mathrm{BP})$ and the pathogen-induced Tsuga decline coincident with a fire (4700 yr BP). In each case following disturbance the sample locations along the DECORANA axes shift towards the centroid of Zone III samples and then revert back approximately to the pre-disturbance 

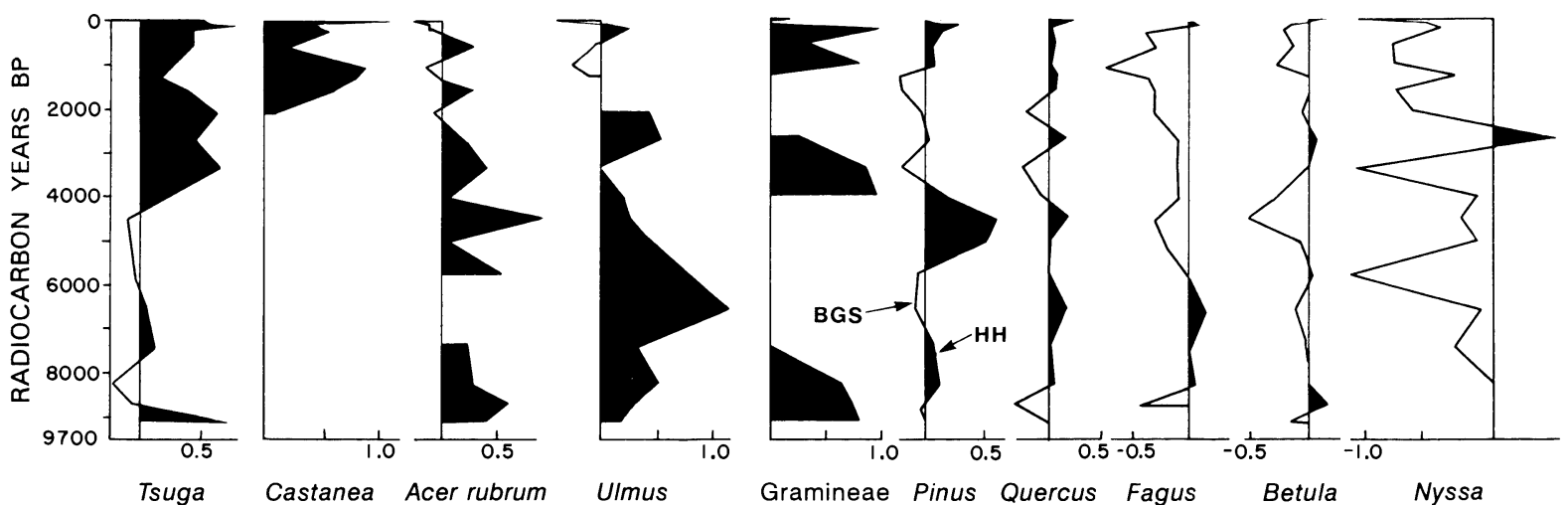

FIG. 12. Log-ratio difference diagram for the major taxa occurring at the two sites. Positive values (black) indicate greater pollen percentage for the taxon at the Hemlock Hollow $(\mathrm{HH})$, and negative values (white) greater percentages at the Black Gum Swamp (BGS). See Methods: Log-ratio diagrams and Results: Log-ratio diagrams for further explanation of the technique.

position. This change in sample position reflects the short-term (e.g., 300-500 yr) decrease in Tsuga, accompanied generally by decreases in Fagus, Acer, Fraxinus and Betula and increase in Quercus and Pinus (see Fig. 11B).

After $3000 \mathrm{yr} \mathrm{BP}$ and the arrival of Castanea the trajectories of sample displacements in ordination space following disturbance are distinctly different (Fig. 11C). Once Castanea is present, it, rather than Pinus or Quercus, is the main species to increase upon a decline in Tsuga, and thus the sample movement is upward along Axis 2, reflecting the increase in Castanea. Three major disturbances occur after 3000 yr BP: a pre-settlement fire (1900 yr BP), an initial phase of post-settlement logging accompanied by burning (1760 A.D.), and regional deforestation, agricultural expansion and heavy local cutting ( $\approx 1800-1880$ A.D.). Following the presettlement fire the forest returned to nearly its former composition (Fig. 11C). However, after settlement the changes were more substantial, Tsuga never recovered its prior abundance, and the samples move through a new region on the DECORANA axes (Fig. 11D). During the recent reforestation (1800-present) and after the initial post-settlement cutting, the stand positions reflect increased percentages of arboreal species-especially Pinus, Quercus, and Tsuga, and the loss of Castanea to blight - in their movement back towards Zone III.

\section{Log-ratio diagrams}

The analysis of taxon-by-taxon differences between the two sites (Fig. 12) shows four major patterns: (1) taxa that are represented in greater abundance at $\mathrm{HH}$ than BGS, including Castanea, Acer rubrum, Ulmus, and Gramineae, (2) taxa, including Pinus and Quercus, that alternate in abundance between the sites throughout the post-glacial, (3) taxa, including Fagus and Betula, that vary in abundance between the two sites through the early Holocene (approximately through Zone III; 7000 yr BP) but subsequently are represented in greater abundance at BGS, and (4) taxa, like Nyssa, that are consistently more abundant at BGS.

With the exception of Nyssa, which grows locally in BGS, the difference diagrams provide some indication of the importance of the taxa locally at $\mathrm{HH}$ relative to their regional abundance. However, it must be recognized that variations in pollen production and dispersal will also affect species representation in basins of different size. Thus, Castanea and Ulmus were more important immediately around $\mathrm{HH}$ than they were throughout the general region. Ulmus was locally important only through the mid-Holocene, after which it declined substantially. Tsuga, the dominant species at $\mathrm{HH}$ since $8000 \mathrm{yr} \mathrm{BP}$, regained its former abundance locally at $\mathrm{HH}$ following the Tsuga decline, but not on a regional basis (cf. Gaudreau 1986, Patterson and Backman 1988; Figs. 7 and 8). Castanea pollen appears at low percentages at $\mathrm{HH}$ before BGS and becomes dominant around $\mathrm{HH}$ after local disturbances. Regionally it was never abundant in the pollen rain, and reached peak values only after settlement.

Pinus and Quercus (pattern 2) occurred in the Tsuga forest around $\mathrm{HH}$ and also were major constituents of the regional vegetation. The difference diagrams for these two taxa largely document events at $\mathrm{HH}$ that change their local abundance. Following the fire at 7650 yr BP Quercus increases at $\mathrm{HH}$ but shows little change regionally. At the onset of the Tsuga decline $(\approx 4700$ yr BP) both Pinus and Quercus increase at $\mathrm{HH}$, whereas Pinus decreases regionally. During the last 200-150 yr Quercus and then Pinus decreased regionally before increasing late in post-settlement times.

Fagus and Betula (pattern 3) occur regionally and at $\mathrm{HH}$ throughout the Holocene. However, at the time of the Tsuga decline they increased regionally, whereas Pinus and Quercus were the major taxa that increased at HH. After the decline Fagus and Betula continued to be less important locally than regionally, whereas Tsuga is more abundant around HH. Before $7000 \mathrm{yr}$ BP Nyssa (4) was locally present in the lowland setting 
around BGS and HH. After 6000 yr BP Nyssa became abundant in BGS, whereas at $\mathrm{HH}$ it is only important during the Tsuga decline.

\section{Discussion}

An understanding of the sedimentological characteristics and pollen source-area relationships of the two sites is critical to the interpretation of the historical records. The continuity and resolution of the two records are discussed below, followed by an examination of changes in the regional vegetation. Within this regional context we then present a detailed examination of trends in the Tsuga stand focusing on long-term vegetation patterns, the history of natural and anthropogenic disturbances, and changing vegetation response to disturbance.

\section{Continuity of the sedimentary records}

The two sites investigated present very different sedimentological environments and contain lithologically distinct stratigraphies. At Black Gum Swamp (BGS) the record extends to $\approx 12500 \mathrm{yr} \mathrm{BP}$. The absence of sharp discontinuities in the pollen stratigraphy or lithology (e.g., abrupt changes in mineral constituents or presence of deeply humified layers of peat) suggests continuous deposition without any significant hiatus (Jacobson and Bradshaw 1981), which is consistent with the records from other wetlands in the region (Davis 1958, Gaudreau 1986). The change in lithology from lake sediment to peat is associated with a shift in sediment accumulation rate and organic content (cf. Davis 1958, Zebryk 1991). The presence of discrete layers of charred wood fragments in the peat indicates fires on the mire surface at the coring site (Tolonen 1985, Patterson et al. 1987). The thinness of these horizons suggests low-intensity surface fire rather than deep burning of peat (W. Patterson, personal communication). However, peat at the surface of a mire has such low compaction that even the removal of the upper $15-20 \mathrm{~cm}$ by a fire would result in a $<200-\mathrm{yr}$ hiatus in the record (Zebryk 1991).

The temporal resolution of the BGS core should be high, a conclusion supported by the distinct changes in the pollen stratigraphy and the discrete charcoal horizons. The rate of sedimentation through the lake stage of development ( $480-250 \mathrm{~cm}$ depth) ranges from $\approx 0.05$ to $0.17 \mathrm{~cm} / \mathrm{yr}$, which is similar to other lakes studied in the northeastern U.S. (Gaudreau 1986). The accumulation rate of the peat is considerably lower $(\approx 0.02 \mathrm{~cm} / \mathrm{yr})$. However, peat is a well-consolidated matrix that undergoes very little vertical mixing and therefore should be appropriate for studies requiring temporal resolution of $100 \mathrm{yr}$ or less (Tolonen 1985, Turner and Peglar 1988).

At the Hemlock Hollow $(\mathrm{HH})$ the great age of the record, the shallow depth of sediment, and the small basin size raise concerns about temporal continuity and resolution. Stratigraphically, the sediment shows no major lithological change, no sudden change in organic content, nor any other evidence of desiccation or hiatus. The pollen record appears continuous when compared against regional records (Davis 1958, Gaudreau 1986) including the BGS diagram, and by the absence of breaks in biostratigraphy or large percentages of corroded and degraded pollen (Bradshaw 1981). The palynological record at $\mathrm{HH}$ contains evidence of moisture surplus throughout the Holocene; Typha/Sparganium is present throughout and Ilex, Alnus, and Sphagnum are present nearly continuously. The stratigraphic evidence indicates slow, continuous deposition with little change in rate during the last $9500 \mathrm{yr}$.

The small size of $\mathrm{HH}$ would appear to render it susceptible to stratigraphic disruption (e.g., by large mammals), while the slow sedimentation rate might make the record susceptible to blurring through sediment mixing (e.g., by invertebrates; Janssen 1967). However, the detail of the biostratigraphic evidence suggests that no major disturbance has occurred, and the discrete nature of the charcoal horizons suggests that little vertical mixing has taken place. Microscopic charcoal analysis confirms that minimal mixing of charcoal horizons into the adjacent sediment has occurred. The only prolonged band of charcoal $(3 \mathrm{~cm})$ occurs in the post-settlement phase where sediments are not compact and repeated light burning is a likely possibility.

The absence of evidence of mixing does not preclude temporal blurring of events. The slow rate of sedimentation at $\mathrm{HH}$ should result in each pollen sample $(\approx 20 \mathrm{~mm}$ thick) encompassing $\approx 30 \mathrm{yr}$ and a separation of $\approx 100-150 \mathrm{yr}$ between adjacent $1-\mathrm{cm}$ samples. Thus major episodes of vegetation change should be detectable, although some short-lived phenomena and minor changes may go undetected.

\section{Pollen source area}

The pollen source areas of the two sites are apparently quite distinct; BGS receives a major component of regional upland pollen as well as pollen from the local swamp taxa, whereas $\mathrm{HH}$ receives primarily pollen of local upland species and a component of regional pollen (cf. Spear and Miller 1976, Jacobson and Bradshaw 1981, Bradshaw 1988, Mitchell 1988). The coring site at the Swamp is located $\approx 75 \mathrm{~m}$ from the nearest upland margin. Thus it should receive considerable pollen from swamp taxa, e.g., Picea, Nyssa, Acer rubrum, Ilex, Osmunda, and Sphagnum (Janssen 1984). The upland pollen that it receives will have been mixed in the air currents passing above the site and should therefore contain regional pollen (i.e., within $10 \mathrm{~km}$ ) as well as limited amounts from the swamp margin and surrounding hillslopes (Turner 1970, Janssen 1973, Jacobson and Bradshaw 1981).

$\mathrm{HH}$, in contrast, is overhung by upland trees. Currently there is a gap in the canopy $\approx 3 \times 10 \mathrm{~m}$ wide, and the presence of light-demanding taxa such as $T y$ - 
pha, Ilex, and Alnus throughout the Holocene record indicates the continual existence of at least partial canopy opening. The canopy opening does allow incursion of pollen from sub-regional sources, e.g., Platanus and Tilia, which are rare at the Harvard Forest, and the settlement horizon of Ambrosia and Chenopods. The inclusion of this regional component is an invaluable aid in biostratigraphic correlation. However, the tall canopy of forest trees immediately around $\mathrm{HH}$ probably provides the bulk of the pollen while also screening particulate matter and providing shelter from wind (Heide and Bradshaw 1982). The absence of any overland flow eliminates water as a mechanism for pollen transport and indicates that coarse fragments such as charcoal are derived locally (Tolonen 1985, Patterson et al. 1987).

Palynological evidence of the pollen source area for the two sites is provided by comparing species that contrast greatly in their pollen production and dispersal characteristics. Ambrosia, a well-dispersed and prolific pollen producer, is a ubiquitous indicator of arable field cultivation. It reaches values of $15-20 \%$ in post-settlement lake sediments in central New England (Davis 1958, Gaudreau 1986) and consistently exceeds $10 \%$ at BGS, with a maximum value of $15 \%$. At $\mathrm{HH}$, where Ambrosia never grew (Foster 1992), post-settlement values range between 1 and $4 \%$. In contrast, Castanea is greatly underrepresented in the regional pollen rain (Whitehead and Bentley 1963, Paillet et al. 1992) and generally reaches $3-10 \%$ in lake sediments. Castanea percentages at BGS range from 3 to $6 \%$. At $\mathrm{HH}$, where Castanea grew in local abundance (Foster 1992), maximum pollen percentages reach $27 \%$. During three separate periods of active Castanea expansion percentages ranged from 18 to $25 \%$.

An additional check on the spatial resolution and variation of pollen records from the Tsuga stand has been provided recently by the analysis of two humus soil cores on two sides of HH (Foster et al. 1992). The two pollen records extend to presettlement time and agree very well through this period with forest histories and reconstructions of the stand, and with the record from $\mathrm{HH}$. This analysis appears to confirm that at $\mathrm{HH}$ the major component of the pollen signal is derived from local, stand-level vegetation (i.e., within $50 \mathrm{~m}$ ), but with a notable sub-regional component.

\section{Regional vegetation history}

The earliest pollen zone at BGS (Zone I) represents a transitional period from $\approx 12500$ to $11800 \mathrm{yr} \mathrm{BP}$ when shrub-tundra was replaced by open woodland dominated by Picea, diploxylon pine (cf. P. banksiana) and Populus. Taxa indicative of open tundra include graminoids ( $40 \%$ of total pollen), Saxifragaceae, Caryophyllaceae, Rosaceae, Artemisia, Compositae, Epilobium, and Shepherdia. Picea and NAP (non-arboreal pollen) percentages conform closely to values obtained from tundra or forest-tundra surface samples (Davis and Webb 1975).

Regional warming initiated the Picea increase in Zone II (1 $1800-9350$ yr BP) and the decline in arctic herbs. Low percentages for Pinus and Betula suggest that these taxa were minor components of the Picea forest in which Larix and Abies also occurred (Davis and Jacobson 1985). Low percentages of Tsuga, Fagus, Acer rubrum, Ulmus, and Fraxinus in the latter half of Zone II suggest the presence but low abundance of temperate species.

Early Holocene warming initiated the rapid decrease in Picea, which was replaced by Pinus, Betula, and Alnus, and later by Quercus, in Zone III (9350-8350 yr BP; Davis 1958, 1969, Ogden 1959, Whitehead 1979). Picea and Tsuga persisted during this period at HH, possibly accompanied by Ulmus, Acer rubrum, and Fraxinus.

Pinus decreases slowly during Zone IV (8350-1750 yr BP) as Tsuga and temperate deciduous taxa such as Quercus, Fagus, and Betula increase. The forest vegetation in central New England during this period was transitional relative to sites elsewhere throughout New England. At Rogers Lake, $200 \mathrm{~km}$ to the south, percentages for Quercus are three times higher than at BGS, whereas Tsuga percentages are less than half as great (Davis 1969). Pollen percentages for major arboreal taxa at BGS are more directly comparable to those obtained from more northern and higher elevational sites such as Berry Pond, Massachusetts (Whitehead 1979), Pownal Bog, Vermont (Whitehead and Bentley 1963), and Mirror Lake, New Hampshire (Likens and Davis 1975). However, the pollen spectra from BGS differ from this hemlock-northern hardwoods assemblage in that Acer saccharum is less important and Quercus and Pinus occur in greater percentages.

By 5000 yr BP, shortly before the Tsuga decline, Tsuga rises to a maximum of $38 \%$ and is accompanied by Quercus, Betula, Fagus, Acer rubrum, Pinus, Fraxinus, and Ulmus. At this time most sites across northcentral to northeastern North America show maximum Tsuga percentages. The Tsuga decline at 4700 yr BP reflects the decimation of Tsuga populations throughout the northeast (Davis 1981, Webb 1982). Subsequently, Quercus, Betula, and Fagus, and later Pinus, became codominant around BGS and throughout most of central New England. Relatively high postdecline percentages at $\mathrm{HH}$ suggest that a local population of Tsuga continued to exist in the watershed (cf. Allison et al. 1986), although sediment mixing or redeposition may create some smoothing of the pollen record.

Increased Picea and Tsuga percentages may signify a shift to a cooler and possibly moister climate around 3300 yr BP (Davis et al. 1980, Gaudreau 1986). Castanea becomes an important regional forest component around 2000 yr BP (Davis 1969, Whitehead 1979). At 
$\mathrm{HH}$, Fagus, a northern-hardwoods species, declines as Tsuga and, later, Castanea increase, which suggests that Fagus was unable to compete successfully with these species, and, in particular, fast-growing Castanea. This apparent interaction between Fagus and Castanea can be seen in other pollen sequences in central and southern New England (Deevey 1943, Davis 1958, 1969, Whitehead 1979); at northern sites Fagus appears to decline in response to increases in Picea, Tsuga, and/or Pinus (Whitehead and Bentley 1963, McDowell et al. 1971, Likens and Davis 1975, Whitehead and Jackson 1990), although climate change may also be involved (Gajewski 1988).

Forest clearance and agriculture in the BGS watershed is evident after $200 \mathrm{yr}$ BP, with substantial increases in agricultural indicators including Ambrosia and grass and decreases in Quercus, Tsuga, and Fagus. Castanea, a rapid-growing species and prolific sprouter, increases greatly. Initial settlement activity in Prospect Hill and the township of Petersham commenced in the 1750s and intensified in the 1790s (Raup and Carlson 1941, Barraclough 1949, Foster 1992). Peak agricultural activity occurred around 1850 , the date we assign to the Ambrosia maximum. Subsequent land abandonment resulted in the reforestation of old fields, first by Betula populifolia and later by Pinus and Quercus and in a decrease in ruderal species (Cline et al. 1938, Brugam 1978, Spear and Miller 1976). The decline in Castanea pollen percentages in near-surface sediments is due to the blight that infected all overstory Castanea trees in Petersham by 1913 (Kittredge 1913).

\section{Vegetation history at the Hemlock Hollow}

The inferred history of the forest around HH includes a brief period of boreal forest in the early Holocene and a lengthy period through the rest of the Holocene dominated by Tsuga-northern hardwoods. This latter period is punctuated with occasional disturbances by fire, pathogens, and human activity that initiate short- to moderate-length periods of vegetation development, each leading back to Tsuga dominance.

The early Holocene forests (primarily Zone III; 9350 8350 yr BP) were comprised of Picea, Populus, Pinus, and Abies. The local vegetation around $\mathrm{HH}$ is distinguished from the regional vegetation by greater amounts of Picea, Populus, Acer rubrum, and Ulmus, with less Pinus. Thus the landscape mosaic at the time may have included Pinus and Quercus dominating the uplands, with low-lying areas supporting mesic assemblages of Picea, Acer rubrum, and Ulmus, and Cyperaceae, Gramineae, Compositae, and Salix. Despite the coniferdominated and presumably flammable nature of the vegetation (cf. Heinselman 1981, Wein 1983) there is no evidence for fire in terms of macroscopic charcoal layers or abrupt changes in biostratigraphy.

During the last 8000 yr Tsuga has dominated the $\mathrm{HH}$ core, contributing $25-40 \%$ of the pollen. This period of single-species importance is marked by long- term changes in associated species, presumably controlled by environmental change and species migrations, and shorter-term stand dynamics influenced by disturbance. Before the Tsuga decline (4700 yr BP) the pollen resembles the Tsuga-northern hardwood assemblage, with Tsuga, Fagus, Acer saccharum, Betula, Quercus, Ulmus, Acer rubrum, and Pinus. In the mid-Holocene, Ulmus decreases, Fraxinus, Carya, Juglans, and Picea increase, and Castanea pollen appears consistently in the record. Following the Tsuga recovery $(\approx 3500 \mathrm{yr} \mathrm{BP})$, Betula and Castanea increase slightly and Fagus begins a gradual decline that continues to the present (cf. Bennett 1985). Following settlement the overall change in the vegetation involves a decrease in Tsuga and Fagus and an increase in Acer rubrum, Betula, and Castanea.

\section{Disturbance history}

The period of Tsuga hardwood forest is characterized by infrequent disturbance by fire, pathogens, and human activity. Some of these disturbances were recorded at both $\mathrm{HH}$ and BGS, and their extent varied from limited (e.g., fire) to subcontinental (e.g., pathogen). The absence of any indication of wind is notable as tropical storms in particular have been proposed as the major natural disturbance factor in central New England (Stephens 1955, Foster 1988). However, the sites investigated are physiographically protected from the southeasterly winds that accompany major tropical storms in this region (Foster and Boose 1992), and wind damage is extremely difficult to detect in the paleoecological record as it leaves no specific stratigraphic marker and must be resolved solely through shifts in the relative abundance of different taxa.

Fire is recorded by macroscopic charcoal horizons. Interpretation of the fire intensity is problematical and must rely on inference from the nature of the vegetation response: specifically, the decline in fire-sensitive species such as Tsuga and northern hardwoods. Each charcoal horizon at $\mathrm{HH}$ is followed by a reduction in Tsuga and in some combination of Fagus, Acer saccharum, A. rubrum, or Ulmus, suggesting that mortality occurred in a portion of the canopy trees. The reduction in Tsuga pollen ranges from 3 to $20 \%$, but with the exception of the Tsuga decline at $4700 \mathrm{yr}$ BP its pollen percentages are never $<12 \%$, and recover to pre-disturbance levels within $300-500 \mathrm{yr}$. The partial reduction of the Tsuga population followed by complete recovery suggests that these were patchy surface fires that burned unevenly, leaving residual populations to seed onto the burned areas (cf. Merrill and Hawley 1924, Patterson and Backman 1988). Thin bark and shallow roots make Tsuga a very fire-sensitive species. However, the diverse topography of the site, which is dissected and bordered by wetlands, would serve to provide discontinuities in fuel and flammable substrate. In addition, Tsuga-hardwood stands have relatively little fuel other than leaf litter and humus, and 
thus tend to burn incompletely (W. A. Patterson, personal communication). During historical times two fires have burned the adjoining dry uplands to the north and west of $\mathrm{HH}$ (Harvard Forest Archives, unpublished data). The fires burned intensely and completely across the Quercus-Pinus upland and died at the margins of BGS and Tsuga forest. The topography and substrate of the site and the nature of the vegetation should reduce the intensity of fires around the two coring sites.

This study provides the first Holocene disturbance history for a site in central New England. The record indicates a frequency of fire occurrence intermediate between the northern hardwood areas of western and northern New England, where no fires were detected in over 1000 yr (Backman 1984, Davis 1985), and coastal locations in eastern Massachusetts and Cape Cod, where surface fires every 50-350 yr have maintained an open forest of Quercus and Pinus (Winkler 1985, Patterson and Backman 1988). Similarly, in north-central Maine Anderson et al. (1986) documented considerable variability in fire occurrence through time as well as evidence for disturbance by defoliating insects. The fire record in this study is undoubtedly a conservative estimate of fire occurrence in the broad upland forests of central New England. First, as described above, the sites themselves would have relatively low fire susceptibility based on physiographic and vegetational characteristics. Second, the use of macroscopic charcoal layers as evidence of fires is conservative in that it only records fires that burn the actual coring site and consume enough woody debris to produce charcoal (Tolonen 1985, Patterson et al. 1987).

The pathogen-mediated decline in Tsuga at $4700 \mathrm{yr}$ BP resulted in the greatest Holocene decrease in Tsuga. At both $\mathrm{HH}$ and BGS charcoal horizons indicate that fire burned contemporaneously with the Tsuga decline.

The human history of the Prospect Hill tract is known in detail and serves to explain later disturbance episodes recorded at HH (Raup and Carlson 1941, Foster 1992). From 1740 to 1790 land clearance for agriculture and local timber cutting was accompanied by burning of slash and intact forests. Cutting and debarking of Tsuga for leather tanning occurred locally for a tanning mill erected in 1765 on the roadway 2 $\mathrm{km}$ from $\mathrm{HH}$ (Coolidge 1948, Smith 1950). The reduction in Tsuga and Fagus and increase in Gramineae and Castanea suggest response to local cutting and fire, whereas the presence of Rumex, Plantago, and Carya suggest pasturage (Emerson 1846, Lutz 1930b, Cawley 1960, Patterson and Backman 1988, Robinson and Dickson 1988). The limited amount of Ambrosia and weeds indicates restricted development of cropland at this time (McAndrews 1988).

Following a period of local forest recovery at $\mathrm{HH}$, broad-scale land clearance and increased tillage across the township (1790-1860) is indicated by the increase in agricultural indicators and grass (Foster 1992). For- ests around $\mathrm{HH}$ and BGS were cut repeatedly (Spurr 1956, Foster 1992). At the peak of agricultural expansion (1840-1860), when $\approx 85 \%$ of the Prospect Hill tract was deforested, the Tsuga stand must have comprised an isolated woodlot of cut-over forest adjoining the cut-over swamp forest (Graves and Fisher 1903, Foster 1992).

\section{Vegetation dynamics following disturbance}

Following each of the disturbances documented in the HH stratigraphy, Tsuga declines and subsequently recovers to be the dominant taxon in the stand. The spacing of disturbances through the Holocene and the continual dominance of Tsuga provide an opportunity to evaluate patterns of community response as controlled by type and severity of disturbance and community composition.

The earlier fire occurs at 7650 yr BP during a transitional period when forests comprised of boreal species were replaced by $T$ suga and temperate deciduous species. Coincident with the fire there is a slight and short increase in Pinus and Quercus and decline in Tsuga and such broad-leaved taxa as Acer saccharum, Fraxinus, Fagus, and Ulmus. Thus, the fire temporarily reversed the transition to Tsuga-northern hardwood forest (Fig. 11A).

During the period of Tsuga-northern hardwood forest (8000 yr BP-present) there are two major types of vegetation response to fire depending on the presence or absence of Castanea in the region (cf. Fig. 11A and B vs. $11 \mathrm{C}$ ). In all cases a decrease in Tsuga and a variable group of northern hardwoods coincides with charcoal layers. In the period before Castanea arrives the prominent species increasing after fire include $P i$ nus, Betula, and Quercus (Fig. 8), which are known to be favored by a surface fire regime (Pinchot and Graves 1896, Cline and Spurr 1942, Swain 1978). At HH this vegetation response leads to the characteristic pattern of movement of samples in the ordination space from areas of high Tsuga loadings toward Pinus, Betula, and Quercus (Fig. 11A and B).

Following fire that occurred after the arrival of Castanea the post-fire vegetation response differs substantially (Fig. 11C and D): Tsuga and northern hardwoods decline; however, Castanea is the major species that increases. Quercus and Pinus show much less response and Betula decreases. Thus it appears that the compositional change resulting from the arrival of Castanea changed the competitive balance within the forest and thereby the community response to disturbance (cf. Watts 1973, Davis 1981). Castanea, a prolific sprouter and rapidly growing tree, is evidently able to exploit the open conditions following partial removal of the canopy by fire (Frothingham 1912, Nichols 1913) more effectively than the prior opportunistic species Pinus, Quercus, and Betula. Castanea is clearly favored by disturbance; it came to dominate the upland forest 
after the extensive disturbance following settlement (Spurr 1956, Paillet 1988, Foster 1992).

The Tsuga decline, although accompanied by a fire, elicits a different response than fire alone-and a contrasting response at the two sites. Although northern hardwood species (Fagus, Betula, Acer saccharum) decline initially with Tsuga, presumably as a result of the fire, they recover and are important for much of the extended period of Tsuga decline. At HH Nyssa increases greatly and then declines upon the recovery of Tsuga beginning at $4000 \mathrm{yr}$ BP. Presumably the Tsuga decline differed from a fire in that broad upland and lowland areas where affected by the long-term reduction of a single species. The loss of lowland Tsuga around $\mathrm{HH}$ favored Nyssa. At BGS Nyssa subsequently remained one of the dominant species on the site through to the present. Although Tsuga recovered completely at $\mathrm{HH}$ following the decline, regionally it never returned to its former abundance (cf. Davis 1958, Gaudreau 1986; Fig. 12). This difference may indicate that whereas Tsuga was widespread across the uplands and lowlands before the decline, its subsequent recovery was limited to the local sites where it occurs in the pre-settlement and modern landscape.

As judged by the change in abundance of individual taxa, by the comprehensive compositional change as reflected in the pollen diagrams and DECORANA graphs (Figs. 9, 10, and 11), and by the historical documentation of physiognomic changes in the vegetation, the post-settlement land-use activities were the most severe disturbances to affect the local and regional vegetation throughout the Holocene. The early phase of subsistence activity, which involved burning, resulted in a vegetation response quite similar to that following the pre-settlement fire $1900 \mathrm{yr}$ BP. Tsuga and northern hardwoods declined and Castanea increased. The associated increase in agricultural indicators is presumably a regional record; however, the peak in grass may also represent a local response to light fire and open vegetation. A reduction in disturbance intensity, signaled by the absence of charcoal, resulted in a recovery of Tsuga and a decrease in Gramineae and Castanea.

Active cutting of the stand for Pinus and Tsuga (17901880; Spurr 1956, Foster 1992) and regional land clearance promoted a very different response. Castanea and Acer rubrum increased locally along with Betula (probably $B$. populifolia), which may also have been important in adjacent pasture areas (Cline et al. 1938, Black and Wescott 1959). The fluctuations in the abundance of Castanea during the period 1790-1900 is probably an indication of cutting of this species around HH for tanbark and poles (Spurr 1956, Foster 1992). The fact that these changes in the abundance of Pinus, Tsuga, and Fagus and increases in Acer rubrum, Ostrya, Castanea, and Betula are also regional events is documented by the diagram from BGS. During the past century Castanea has declined as a result of the blight, while reforestation and succession have led to an in- crease in Pinus, Tsuga, and Quercus and a decline in agricultural indicators, grass, and Betula.

\section{CONCLUSION}

Pollen analysis of large sedimentary basins records vegetation history over a wide area and is unable to resolve the complex vegetation pattern existing in physiographically diverse landscapes like central New England. Analysis of a very small basin in this study has provided a local record of vegetation dynamics in a sheltered, mesic site. The results confirm that Tsuga canadensis has been the dominant component of the forest for $8000 \mathrm{yr}$ (cf. Spear and Miller 1976). The study does not support the notion that long-term stand dynamics necessarily involve an alternation of dominant species (e.g., hardwoods and Tsuga; Hough 1936, Woods and Whittaker 1981), but instead documents the changing abundance of major tree species (Tsuga and northern hardwoods vs. Pinus, Quercus, or Castanea) following disturbance. The results distinguish distinct phases of human activity during the past three centuries and confirm that regional and local pollen assemblages remain distinct from pre-settlement assemblages despite more than 125 yr of widespread reforestation.

\section{ACKNOWLEDGMENTS}

The development of this project has benefitted greatly from suggestions by N. Arens, M. Davis, D. Gaudreau, S. Jackson, F. Paillet, W. Patterson, P. Schoonmaker, L. Tennant, G. Whitney, and an anonymous reviewer. Technical assistance has been provided by E. Boose, B. Flye, B. Hoadley, A. Lezberg, E. Moriarty, and D. Smith. We gratefully acknowledge W. Patterson for use of laboratory facilities at the University of Massachusetts. Funding was provided by the National Science Foundation, A. W. Mellon Foundation, and U.S. Geological Survey. This paper is a contribution of the Long-Term Ecological Research Program at the Harvard Forest.

\section{Literature Cited}

Allison, T. D., R. E. Moeller, and M. B. Davis. 1986. Pollen in laminated sediments provides evidence for a mid-Holocene forest pathogen outbreak. Ecology 67:1101-1105.

Anderson, R. S., R. B. Davis, N. G. Miller, and R. Stuckenrath. 1986. History of late- and post-glacial vegetation and disturbance around Upper South Branch Pond, northern Maine. Canadian Journal of Botany 64:1977-1986.

Backman, A 1984. 1000 year record of fire-vegetation interactions in the northeastern United States: a comparison between coastal and inland regions. Thesis. University of Massachusetts, Amherst, Massachusetts, USA.

Barraclough, S. L. 1949. Forest land ownership in New England. Dissertation. Harvard University, Cambridge, Massachusetts, USA.

Bennett, K. D. 1985. The spread of Fagus grandifolia across eastern North America during the last 18,000 years. Journal of Biogeography 12:147-164.

Bennett, K. D., and H. F. Lamb. 1988. Holocene pollen sequences as a record of competitive interactions among tree populations. Trends in Ecology and Evolution 3:141144.

Black, J. D., and G. W. Wescott. 1959. Rural planning of one county, Worcester County, Massachusetts. Harvard University Press, Cambridge, Massachusetts, USA.

Bormann, F. H., and M. F. Buell. 1964. Old-age stands of 
hemlock northern hardwood forest in central Vermont. Bulletin of the Torrey Botanical Club 91:451-465.

Bradshaw, R. H. W. 1981. Modern pollen-representation factors for woods in south-east England. Journal of Ecology 69:45-70.

1988. Spatially-precise studies of forest dynamics. Pages 725-751 in B. Huntley and T. Webb, editors. Vegetation history. Kluwer, Dordrecht, The Netherlands.

Brugam, R. B. 1978. Pollen indicators of land-use change in southern Connecticut. Quaternary Research 9:349-362.

Cawley, E. T. 1960. Phytosociological study of the effect of grazing of southern Wisconsin woodlots. Dissertation. University of Wisconsin, Madison, Wisconsin, USA.

Clark, J. S. 1990. Fire and climate change during the last $750 \mathrm{yr}$ in northwestern Minnesota. Ecological Monographs 60:135-159.

Clark, R. L. 1982. Point count estimation of charcoal in pollen preparations and thin sections of sediments. Pollen et Spores 24:523-535.

Cline, A. C., N. L. Munster, R. J. Lutz, and M. E. Raymond. 1938. The farm woodlands of the town of Hardwick, Massachusetts. Worcester County Land Use Planning Project. Harvard University, Cambridge, Massachusetts, USA.

Cline, A. C., and S. H. Spurr. 1942. The virgin upland forest of central New England. A study of old growth stands in the Pisgah mountain section of southwestern New Hampshire. Harvard Forest Bulletin 21.

Coolidge, M. C. 1948. The history of Petersham, Massachusetts. Powell, Hudson, Massachusetts, USA.

Davis, M. B. 1958. Three pollen diagrams from central Massachusetts. American Journal of Science 256:540-555.

- 1969. Climatic changes in southern Connecticut recorded by pollen deposition at Rogers Lake. Ecology 50: 409-422.

- 1981. Outbreaks of forest pathogens in forest history. Pages 216-227 in Proceedings of the Fourth International Palynological Conference (1976-1977). Volume 3. Birbal Sahni Institute of Paleobotany, Lucknow, India.

. 1985. History of the vegetation on the Mirror Lake Watershed. Historical considerations. Pages 53-65 in G. E. Likens, editor. An ecosystem approach to aquatic ecology. Springer-Verlag, New York, New York, USA.

Davis, M., and D. B. Botkin. 1985. Sensitivity of cooltemperate forests and their fossil pollen record to rapid temperature change. Quaternary Research 23:327-340.

Davis, M. B., R. W. Spear, and L. C. K. Shane. 1980. Holocene climate of New England. Quaternary Research 14: 240-250.

Davis, R. B., and G. L. Jacobson. 1985. Late-glacial and early Holocene landscapes in northern New England and adjacent areas of Canada. Quaternary Research 23:341368.

Davis, R. B., and T. Webb, III. 1975. The contemporary distribution of pollen from eastern North America: a comparison with the vegetation. Quaternary Research 5:395434.

Dean, W. E. 1974. Determination of carbonate and organic matter in calcareous sediments and sedimentary rock by loss on ignition: comparison with other methods. Journal of Sedimentary Petrology 44:242-248.

Deevey, E. S., Jr. 1943. Additional pollen analyses from southern New England. American Journal of Science 241: $717-752$.

-. 1951. Late-glacial and postglacial pollen diagrams from Maine. American Journal of Science 249:177-207.

Emerson, G. B. 1846. A report on the trees and shrubs growing naturally in the forests of Massachusetts. Little, Brown \& Company, Boston, Massachusetts, USA.

Faegri, K. 1954. On age and origin of the beech forest (Fagus silvatica L.) at Lygrefjorden near Bergen, Norway. Danmarks Geologiske Undersøgelse 80:230-249.
Faegri, K., and J. Iversen. 1975. Textbook of pollen analysis. Third edition. Hafner, New York, New York, USA.

Foster, D. R. 1988. Disturbance history, community organization and vegetation dynamics of the old-growth Pisgah Forest, south-western New Hampshire, U.S.A. Journal of Ecology 76:105-134.

- 1992. Land-use history (1733-1990) and vegetation dynamics in central Massachusetts, USA. Journal of Ecology 80 , in press.

Foster, D. R., and E. Boose. 1992. Patterns of forest damage resulting from catastrophic wind in central New England, U.S.A. Journal of Ecology 80:79-98.

Foster, D. R., P. K. Schoonmaker, and S. T. A. Pickett. 1990. Insights from paleoecology to community ecology. Trends in Ecology and Evolution 5:119-122.

Foster, D. R., T. Zebryk, P. K. Schoonmaker, and A. Lezberg. 1992. Land-use history and vegetation dynamics of a hemlock forest in central New England. Journal of Ecology 80, in press.

Frothington, E. H. 1912. Second-growth hardwoods in Connecticut. USDA Forest Service Bulletin 96. United States Government Printing Office, Washington, D.C., USA.

Gajewski, K. 1988. Late Holocene climate changes in eastern North America estimated from pollen data. Quaternary Research 29:255-262.

Gaudreau, D. C. 1986. Late-Quaternary vegetational history of the northeast: paleoecological implications of topographic patterns in pollen distributions. Dissertation. Yale University, New Haven, Connecticut, USA.

Gaudreau, D. C., and T. Webb, III. 1985. Late-Quaternary pollen stratigraphy and isochrone maps for the northeastern United States. Pages 247-280 in V. M. Bryant and R. G. Holloway, editors. Pollen records of late-Quaternary North American sediments. American Association of Stratigraphic Palynologists Foundation, Dallas, Texas, USA.

Graves, H. S., and R. T. Fisher. 1903. The woodlot: a handbook for owners of woodlands in southern New England. USDA Bureau of Forestry Bulletin 42.

Heide, K. M., and R. Bradshaw. 1982. The pollen-tree relationship within forests of Wisconsin and Upper Michigan, U.S.A. Review of Paleobotany and Palynology 36:1-23.

Heinselman, M. L. 1981. Fire intensity and frequency as factors in the distribution and structure of northern ecosystems. Pages 7-57 in H. Mooney, I. M. Bonnicksen, N. L. Christensen, J. E. Loten, and W. A. Reiners, editors. Fire regimes and ecosystem properties. USDA Forest Service General Technical Report WO-26.

Henry, J. D., and J. M. A. Swan. 1974. Reconstructing forest history from live and dead plant material-an approach to the study of forest succession in southwest New Hampshire. Ecology 55:772-783.

Hill, M. O., and H. G. Gauch. 1980. Detrended correspondence analysis: an improved ordination technique. Vegetatio 42:47-58.

Hough, A. F. 1936. A climax forest community on east Tionesta Creek in northwestern Pennsylvania. Ecology 17: 9-28.

Hough, A. F., and R. D. Forbes. 1943. The ecology and silvics of forests in the high plateaus of Pennsylvania. Ecological Monographs 13:299-320.

Jacobson, G. L. 1979. The paleoecology of white pine (Pinus strobus) in Minnesota. Journal of Ecology 67:697-726.

Jacobson, G. L., and R. H. W. Bradshaw. 1981. The selection of sites for paleoenvironmental studies. Quaternary Research 16:80-96.

Janssen, C. R. 1967. A post-glacial pollen diagram from a small Typha swamp in northwestern Minnesota interpreted from pollen indicators and surface samples. Ecological Monographs 37:145-171.

․ 1973. Local and regional polien deposition. Page 
326 in H. J. B. Birks and R. G. West, editors. Quaternary Plant Ecology, Blackwells, Oxford, England.

1984. Modern pollen assemblages and vegetation in the Myrtle Lake Peatland, Minnesota. Ecological Monographs 54:213-252.

Kelty, M. J. 1986. Development patterns in two hemlockhardwood stands in southern New England. Canadian Journal of Forest Research 16:885-891.

Kittredge, J. 1913. Notes on the chestnut bark disease in Petersham, Massachusetts. Harvard Forestry Club Bulletin 2:13-22.

Likens, G. E., and M. B. Davis. 1975. Post-glacial history of Mirror Lake and its watershed in New Hampshire, U.S.A. an initial report. Verhandlungen der Internationalen Vereinigung für theoritische und angewandte Limnologie 19: 982-993.

Lutz, H. J. 1930a. The vegetation of Heart's Content, a virgin forest in northwestern Pennsylvania. Ecology 11:129.

- 1930b. Effect of cattle grazing on vegetation of a virgin forest in northwestern Pennsylvania. Journal of Agricultural Research 41:561-570.

Marshall, R. 1927. The growth of hemlock before and after release from suppression. Harvard Forest Bulletin 11

McAndrews, J. H. 1988. Human disturbance in North American forests and grasslands: the fossil pollen record. Pages 673-698 in B. Huntley and T. Webb, editors. Vegetation history. Kluwer, Dordrecht, The Netherlands.

McDowell, L. L., R. M. Dole, Jr., M. Howard, Jr., and R. A. Farrington. 1971. Palynology and radiocarbon chronology of Bugbee Wildflower Sanctuary and Natural Area, Caledonia County, Vermont. Pollen et Spores 13:73-91.

Merrill, P. H., and R. C. Hawley. 1924. Hemlock: its place in the silviculture of the southern New England forest. Yale University School of Forestry Bulletin 12.

Mitchell, F. J. G. 1988. The vegetation history of the Killarney oakwoods, SW Ireland: evidence from fine spatial resolution pollen analysis. Journal of Ecology 76:415-436.

Motts, W. S., and A. L. O'Brien. 1981. Geology and hydrology of wetlands in Massachusetts. Water Resources Research Center, University of Massachusetts at Amherst Publication 123.

Nichols, G. E. 1913. The vegetation of Connecticut. II. Virgin forests. Torreya 13:199-215.

Niering, W. A., and R. H. Goodwin. 1974. Creation of relatively stable shrublands with herbicides: arresting succession on rights-of-way and pastureland. Ecology 55:784795.

Ogden, J. G., III. 1959. A late-glacial pollen sequence from Martha's Vineyard, Massachusetts. American Journal of Science 257:366-381.

Oliver, C. D., and E. P. Stephens. 1977. Reconstruction of a mixed-species forest in central New England. Ecology 58: 562-572.

Paillet, F. L. 1988. Character and distribution of American chestnut sprouts in southern New England woodlands. Bulletin of the Torrey Botanical Club 115:32-44.

Paillet, F., M. Winkler, and P. Sanford. 1991. Relationship between pollen frequency in moss polsters and forest composition in a naturalized stand of American chestnut: implications for paleoenvironmental interpretation. Bulletin of the Torrey Botanical Club 118:432-443.

Patterson, W. A., and A. E. Backman. 1988. Fires and disease ecology of forests. Pages 603-632 in B. Huntley and T. Webb, editors. Vegetation history. Kluwer, Dordrecht, The Netherlands.

Patterson, W. A., K. J. Edwards, and D. J. Maguire. 1987. Microscopic charcoal as a fossil indicator of fire. Quaternary Science Reviews 6:3-23.
Nicholas, editor. Holocene human ecology in northeastern North America. Plenum, New York, New York, USA.

Pinchot, G., and H. S. Graves. 1896. The white pine. Century, New York, New York, USA

Prentice, I. C. 1988. Records of vegetation in time and space: the principles of pollen analysis. Pages 17-42 in B. Huntley and $\mathrm{T}$. Webb, editors. Vegetation history. Kluwer, Dordrecht, The Netherlands.

Raup, H. M., and R. E. Carlson. 1941. The history of land use in the Harvard Forest. Harvard Forest Bulletin 20.

Robinson, D. E., and J. H. Dickson. 1988. Vegetational history and land use: a radiocarbon-dated pollen diagram from Machrie Moor, Arran, Scotland. New Phytologist 109: 223-251.

Rogers, R. S. 1978. Forests dominated by hemlock (Tsuga canadensis): distribution as related to site and postsettlement history. Canadian Journal of Botany 56:843-854.

Schoonmaker, P. K., and D. R. Foster. 1991. Some implications of paleoecology for contemporary ecology. Botanical Reviews 54:204-257.

Smith, E. E. 1950. Eastern hemlock: its relationship to the silvicultural policy of the Harvard Forest. Thesis. Harvard University, Cambridge, Massachusetts, USA.

Spear, R. W., and N. G. Miller. 1976. A radiocarbon-dated pollen diagram from the Allegheny Plateau of New York State. Journal of the Arnold Arboretum 57:369-401

Spurr, S. H. 1956. Forest associations in the Harvard Forest. Ecological Monographs 26:245-262.

Stephens, E. P. 1955. The historical-developmental method of determining forest trends. Dissertation. Harvard University, Cambridge, Massachusetts, USA.

Swain, A. M. 1978. Environmental changes during the past 2000 years in north-central Wisconsin: analysis of pollen, charcoal, and seeds from varved lake sediments. Quaternary Research 10:55-68.

Tolonen, M. 1985. Palaeoecological reconstruction of vegetation in a prehistoric settlement area, Salo, SW Finland. Annales Botanici Fennici 22:101-116.

Turner, J. 1970. Post-Neolithic disturbance of British vegetation. Pages 150-281 in D. Walker and R. G. West, editors. Studies in the vegetational history of the British Isles. Cambridge University Press, London, England.

Turner, J., and S. M. Peglar. 1988. Temporally-precise studies of vegetation history. Pages 753-778 in B. Huntley and T. Webb, editors. Vegetation history. Kluwer, Dordrecht, The Netherlands.

Watts, W. A. 1973. Rates of change and stability in vegetation in the perspective of long periods of time. Pages 195206 in H. J. B. Birks and R. G. West, editors. Quaternary plant ecology. John Wiley \& Sons, New York, New York, USA.

Webb, T., III. 1982. Temporal resolution in Holocene pollen data. Pages 569-572 in Proceedings of the Third North American Paleontological Convention. Volume 2. Business and Economic Service, Toronto, Ontario, Canada.

Wein, R. 1983. The role of fire in northern circumpolar ecosystems. John Wiley \& Sons, Chichester, England.

Westveld, M. 1956. Natural forest vegetation zones of New England. Journal of Forestry 54:332-338.

Whitehead, D. R. 1979. Late-glacial and postglacial history of the Berkshires, Western Massachusetts. Quaternary Research 12:333-357.

Whitehead, D. R., and D. R. Bentley. 1963. A post-glacial pollen diagram from southwestern Vermont. Pollen et Spores 5:115-127.

Whitehead, D. R., and S. Jackson. 1990. The regional vegetational history of the High Peaks (Adirondack Mountains), New York. New York State Museum Bulletin, Num- 
and climate for Cape Cod, Massachusetts. Quaternary Research 23:301-312.

Woods, K. D., and R. H. Whittaker. 1981. Canopy-understory and the internal dynamics of mature hardwood and hemlock-hardwood forests. Pages 305-323 in D. C. West, H. H. Shugart, and D. B. Botkin, editors. Forest succes- sion-concepts and application. Springer-Verlag, New York, New York, USA.

Zebryk, T. 1991. Holocene development of a forested wetland in central Massachustets. Thesis. Harvard University, Cambridge, Massachusetts, USA.

\section{ERRATUM}

In an article by I. C. Prentice, P. J. Bartlein, and T. Webb III ("Vegetation and climate change in eastern North America since the last glacial maximum," Ecology 72:2038-2056), a last-minute addition of new sites from Florida to the data base led to a new set of maps that are inaccurately described in two sentences. On p. 2041 , column 2 , line 16 , the text should read: “. . . isopoll maps show that the distribution patterns for northern and southern pines overlapped from 18000 to 12000 yr BP." On p. 2046, column 2, line 15, the text should read: "Oak was present in the south at $18000-15000$ yr BP, but had a relatively restricted distribution due to low temperatures."

For a description of the changes to the data base, see Chapter 17 by T. Webb III, P. J. Bartlein, S. P. Harrison, and K. H. Anderson ("Vegetation, lake level, and climate change in eastern North America") in $\mathrm{H}$. E. Wright, Jr., J. E. Kutzbach, T. Webb III, W. F. Ruddiman, F. A. Street-Perrott, and P. J. Bartlein, editors. Global climates since the last Glacial Maximum. University of Minnesota Press, Minneapolis, Minnesota, USA, in press. 